\title{
Contrasting patterns in the abundance of fish communities targeted by fishers on two coral reefs in southern Mozambique
}

\author{
Sancelme Tonin 1, 2,3, Goetze $\mathrm{J}^{2,4,5}$, Jaquemet S, Meekan Mg 1,2, Flam A 6, Watts Am 6,7, \\ Speed $\mathrm{Cw}^{1,2}$
}

${ }^{1}$ Australian Institute of Marine Science, Indian Ocean Marine Research Centre, The University of Western Australia, Crawley, Australia

2 Global FinPrint Project, The University of Western Australia, Crawley, Australia

3 Université de La Réunion, UMR 9220 ENTROPIE [Tropical Marine Ecology Laboratory], Institute of Research for Development (IRD)/French National Centre for Scientific Research (CNRS), Saint Denis, Réunion

${ }^{4}$ Department of Environment and Agriculture, Curtin University, Bentley, Australia

${ }^{5}$ Marine Program, Wildlife Conservation Society, Bronx, New York, USA

${ }^{6}$ Marine Megafauna Foundation, Marine Megafauna Research Center, Tofo Beach, Inhambane, Mozambique

${ }_{7}$ Manchester Metropolitan University, Manchester, United Kingdom

* Corresponding author : Tonin Sancelme, email address : tonin.sancelme@laposte.net

\begin{abstract}
:
Coastal populations of maritime countries in eastern Africa rely on fish as a primary source of protein, but baseline information on the abundance of fish communities on these coastlines is often lacking. We used baited remote underwater video stations to compare the abundance and diversity of reef fishes targeted by fishing at two sites in southern Mozambique, one at Lighthouse Reef within the Bazaruto Archipelago National Park and the other to the south at San Sebastian Reef on the San Sebastian Peninsula. Fish that are known targets of fisheries (mostly small-scale and artisanal) had an abundance that was almost three-times greater at San Sebastian Reef (80.22 ind. h-1 [SE 18.00]) than at Lighthouse Reef (29.70 ind. h-1 [SE 8.91]). Similarly, there was greater mean species richness at San Sebastian Reef (38.74 species $h-1$ [SE 2.79]) than at Lighthouse Reef (25.37 species $h-1$ [SE 3.66]). The main drivers of targeted fish abundance were habitat and depth, with shallow $(<15 \mathrm{~m})$ and mixed reef areas having the greatest abundance and richness. More sampling was done over sand habitat at Lighthouse Reef, which likely led to the lower abundance and species richness observed at this site; however, that finding could also be attributable to the fact that protection is provided to only a section of available coral reef habitat in a small area. Nevertheless, fish community structure was comparable between the sites, with similar proportions of carnivores (78-81\%), herbivores (12-14\%) and omnivores (7-8\%). Our findings highlight the variation in species abundance and assemblages of coral-reef fish targeted by fishing in Mozambique and emphasise the importance of localised environmental variables as a driver of these patterns. To
\end{abstract}


ensure maximum protection of Lighthouse Reef fish communities, we recommend an extension of the notake zone to include the entire reef complex.

Keywords: baited remote underwater video, Bazaruto Archipelago, biodiversity, fish community structure, fishing pressure, marine reserve, rarefaction curves, western Indian Ocean 


\section{Introduction}

Fish harvested on coral reefs constitute one of the main sources of protein for communities in developing countries throughout the world (Teh et al. 2013). This is particularly evident in Africa where maritime countries derive the majority of their protein from fish (Belhabib et al. 2019). However, in many instances short-term [check] food security is prioritised over conservation efforts (McClanahan et al 2011), and this has been an important factor leading to the overexploitation of many stocks of coral-reef fishes in East Africa (e.g. Kaunda-Arara et al. 2003; Tuda and Wolff 2015; Samoilys et al. 2017; Belhabib et al. 2019). Poor compliance, resulting from inadequate [check] enforcement, and a lack of baseline information, which is essential for describing long-term trends in abundance, often hamper the success of management strategies and conservation efforts (McClanahan 1999; MacNeil et al. 2015).

Marine reserves [These are not synonymous; some marine reserves allow some exploitation, including the BANP.] have been established as a means of management and conservation for species targeted by fishing throughout many regions of East Africa (e.g. McClanahan and Arthur 2001), with varying levels of success (McClanahan et al. 1999; McClanahan et al. 2007; Currie et al. 2012). In general, such areas prohibit extractive or disruptive activities and provide refuge for maintenance or recovery of marine populations (Ballantine and Langlois 2008). Although the cost of establishing a marine reserve is often lower than that of traditional fisheries management strategies (Roberts and Polunin 1991), effective implementation requires an understanding of traditional rights and international laws, as well as regional fishing practices (Wells et al. 2016). Where reserves have been managed successfully, benefits have included positive effects on biodiversity and ecosystem health over time (e.g. Wells et al. 2016), with an increase in species richness, biomass and density of exploited families of fishes, and protection of habitats for [Associated with what? Do you mean flora and fauna that occur in the reserves?] flora and fauna within the reserves (McClanahan and Kaunda-Arara 1996; McClanahan et al. 2007; Caveen et al. 2015). It is widely accepted that larger reserves can result in increased resilience of coral-reef fish communities to climate change, improve the spillover effect (movement of fishes beyond the boundary of the reserve to where they can be captured by fishers), and reduce the stress induced by the edge effect of the boundary on populations (Wilhelm et al. 2014). However, the placement of a marine reserve is also important, with the selection of high-quality habitat, appropriate water depths and increased distance to human populations and activities all thought to have a positive effect on reserve performance (Wells et al. 2016; Cinner et al. 2018). 
There have been numerous studies of coral-reef fish communities within and outside marine reserves along the coast of eastern Africa (e.g. McClanahan and Arthur 2001). Most of these have focussed on a broad range of demersal fishes associated with coral reefs, without a specific focus on species that are important targets of reef fisheries (e.g. Maggs et al. 2010; Chabanet et al. 2016; Samoilys et al. 2019, although see McClahahan and Jadot 2017). This lack of data on targeted species is concerning, given the importance of such data to baseline monitoring of trends in the status of fish communities. Furthermore, studies to date have generally used underwater visual census (UVC) techniques to survey reefs, which often preferentially record the smaller, site-attached species (Colton and Swearer 2010), rather than larger-bodied and often wider-ranging carnivores, many of which are targeted by fisheries. Better assessments of the status of these targeted species could be obtained with baited remote underwater video stations (BRUVS), which use baits to attract fishes into the field of view of a camera. This technique mostly samples these larger, omnivorous and carnivorous fishes and thus may provide insights into the abundance of the species preferentially targeted in reef fisheries (Watson et al. 2005 Harvey et al. 2007; Bernard et al. 2014). To date, fisheryindependent surveys using BRUVS have been used to quantify fish abundance and biomass in temperate regions of eastern South Africa [If all these studies were conducted in South Africa, it is more precise to write 'eastern South Africa'.] (e.g. Bernard and Gotz 2012; De Vos et al. 2014; Roberson et al. 2015; Heyns-Veale et al. 2016). However, comparatively few surveys have been conducted further north along the tropical coastlines of Mozambique, Kenya, and Tanzania (e.g. Unsworth et al. 2015).

Here, we use BRUVS to describe the coastal fish communities of coral reefs in southern Mozambique. We focus on species targeted by fisheries and we sample both within and outside a marine reserve present along the coast. Our aim is to provide one of the first baseline assessments of the status of targeted fish species and an assessment of the possible role of marine reserves in the management of these resources. Specifically, we hypothesised that: a) targeted fish would be more abundant inside the marine reserve, where fishing practices are limited, compared to outside the marine reserve, which was open to fishing, and b) overall fish abundance and diversity would also be greater inside the marine reserve compared to outside the reserve. [You refer later to testing your hypotheses. You need to specify here what those hypotheses are. Did you hypothesise that fish abundance and species richness (both of targeted species and of all species) are higher inside a no-take area within the BANP than they are outside the BANP? But please see further queries below, under 'Study sites'. It is not clear whether you regard your Lighthouse Reef site as being in the no-take area or not.] The results of our study could be used to inform management and to infer current pressures in the region. In addition to focussing on targeted 
species, we also sampled non-target species, which could be used to provide a more holistic overview of species diversity and relative abundance in the region.

\section{Materials and methods}

Mozambique has a history of research on reef fishes that dates back to the 1930s (Pereira 2000). Much of this work has focussed on assessments of biodiversity (e.g. Maggs et al. 2010), rather than the species targeted by fisheries. The country has more-developed management of marine resources than some other areas of East Africa, and there are a number of well-established marine reserves in Mozambique, such as the Ponto Do Ouro Partial Marine Reserve in the extreme south, and around the Bazaruto Archipelago. The archipelago, composed of five islands (Figure 1) has had protected status since 1971, although initially this only included three islands (Benguérua, Magaruque and Bangué) (Maggs et al. 2010) [reference?]. In 2001, the protected area was enlarged to include all five islands and the legislation was strengthened with the official creation of the Bazaruto Archipelago National Park (BANP) (Maggs et al. 2010) [reference?]. Bazaruto Archipelago National Park was not designed specifically to protect or strengthen resources for artisanal fisheries (Santos 2008), but rather to protect suitable habitat for threatened, vulnerable, and endangered marine megafauna such as dugongs Dugong dugon and sea turtles (green Chelonia mydas, hawksbill Eretmochelys imbricata, loggerhead Caretta caretta, olive ridley Lepidochelys olivacea and leatherback Dermochelys coriacea) (MITUR 2008; van der Elst and Afonso 2008).

Although the initial management goal of the BANP was not to promote the sustainability of fish stocks, in theory the protection offered by the implementation of the park and no-take areas within the park should have flow-on benefits that address some of the issues surrounding overfishing in the region (Russ 1991). However, there has been concern in recent years of a decline in marine resources within BANP including fish, which may have led to some of the impetus for re-zoning and increasing protection of no-take areas or 'Total Marine Protection Zones (ZPTM)' (Diaz et al. 2016). Furthermore, the most recent park management plan also discusses large species of cod / 'rockfish' that are afforded protection throughout all of the park (Diaz et al. 2016). [You refer to the 'initial' management goal. Please could you clarify whether the protection of fish stocks has since explicitly been added to the management goals of the BANP, or whether such protection is just an unintended benefit of protecting megafauna habitat. If it is still not an explicit goal to protect fish stocks, why have no-take areas been declared? This is not clear at present.] 


\section{Study sites}

Two reef sites were sampled during August 2016; one on Bazaruto Island inside the BANP, and the other outside the BANP on the San Sebastian Peninsula (Figure 1). Lighthouse Reef $\left(21^{\circ} 31^{\prime} 00^{\prime \prime} \mathrm{S}, 35^{\circ} 30^{\prime} 14^{\prime \prime} \mathrm{E}\right)$ is situated inside the BANP near the north-eastern tip of Bazaruto Island (Maggs et al. 2010). Here, habitats are mainly composed of hard coral (43\%), bare reef, rubble and sand (32\%), dead coral (9\%) and soft coral (7\%) (MH Schleyer and JQ Maggs, Oceanographic Research Institute, Durban, unpublished data). In general, the park aims to restrict fishing activities such as gillnetting and semi-industrial or industrial fishing. [This is why it is important to clarify why the park aims to restrict certain types of fishing.] Mozambican fishers who do not live inside the BANP are only allowed to use handlines when inside the park, and beach-seines are only permitted in a small zone in the south of Magaruque, the second biggest island in the BANP (Everett et al.2008) [Are there Mozambican fishers who do live inside the BANP? If so, what restrictions apply to them?]. The latest estimate of the population of residents living within the BANP is $>5,000$ people, who are the only people permitted to fish within a specific zone called 'Zones of Use Limited to Local Communities' (Diaz et al. 2016). Fishing is also allowed inside the BANP by non-residents [Please clarify exactly what type of fishing is allowed. You have indicated already that gillnetting and (semi-)industrial fishing are not allowed, and that local fishers can use handlines and, in one location, beach-seines. What else is allowed? Artisanal and recreational linefishing?], although it is totally excluded inside no-take areas or 'Total Marine Protection Zones' (ZPTM), one of which was located at our sampling site at Lighthouse Reef. [When you say 'adjacent to', this implies that your sampling site was not actually in the no-take area. Consistent with this, in Figure 1a, you show the deployment locations of the BRUVS as being outside the no-take area. In the Discussion, however, you imply that your site was in the no-take area. Although you go on to say, below, that the boundaries of the no-take area are unclear, you need to specify whether you considered the Lighthouse Reef site to have been in the no-take area or not. This is particularly important if you were testing the hypothesis that abundance and species richness are higher inside a no-take area within the BANP than they are outside the BANP.] The only activity allowed inside the BANP no-take areas is recreational SCUBA diving and snorkelling. The Lighthouse Reef no-take area includes the main reef complex that is adjacent to the coastline, albeit only covering a section of the available coral reef habitat, which is $<3 \mathrm{~km}^{2}$ (Diaz et al. 2016). In comparison, San Sebastian Reef (22 $\left.02^{\prime} 45^{\prime \prime} \mathrm{S}, 35^{\circ} 33^{\prime} 76^{\prime \prime} \mathrm{E}\right)$ is situated to the south of the archipelago [Please clarify. Is San Sebastian Reef inside the Bazaruto Archipelago but outside the BANP?] within the San Sebastian Coastal Reserve, which was created to afford protection to terrestrial and littoral habitats. The coastal waters beyond the immediate shoreline, including our site, were 
not officially protected at the time of the study and fishing was permitted. [This reference to Lighthouse Reef does not seem to be strictly correct. The waters immediately offshore of the no-take area would not have had complete protection but, because they were in the BANP, there was some official protection (through the restrictions on fishing gear that you describe earlier).] These two reefs were selected for comparison because of similarities in habitat features such as depth (Lighthouse mean = $13.4 \mathrm{~m}$ and San Sebastian mean $=11.1 \mathrm{~m}$ ) and benthic cover (predominantly coral reef and sand). However, it must be acknowledged that Lighthouse Reef within the BANP is situated on an island (Bazaruto), which at the southern end has a channel separating it with Benguerra island [What bay? Can you label it on Figure 1?], whereas San Sebastian Reef is adjacent to the coastline of the mainland, and as such is likely to experience different hydrological patterns and be characterised by differing geomorphology compared to the BANP (See Everett et al. 2008). [ls there a reference that describes the geomorphology?] [You refer in the Discussion to the 'isolation' of San Sebastien Reef, although it is not clear what is meant by the term. You need to describe that here.].

\section{Data collection and video interrogation}

Data were collected over a two-week period from 12 to 20 August 2016 [Table S2 shows 1220 August.]. At each site, BRUVS were used to sample reef fish communities (Supplementary Figure S1). This sampling method uses bait to attract fishes, which makes the technique particularly suited for sampling predatory species that are often targeted by fisheries (Langlois et al. 2012; Goetze et al. 2015), without precluding herbivorous species (Harvey et al. 2007). Our equipment consisted of high-definition video cameras (GoPro Hero4 Silver) in underwater housings, secured in an aluminium frame with a bait bag placed in front of the cameras to attract fish (Supplementary Figure S1). The bait was composed of approximately $1 \mathrm{~kg}$ of crushed mackerel (Scombridae) or sardine (Clupeidae). The use of more than one type of bait was not considered to be problematic, as both types had similar properties in terms of oil content, and studies comparing less-similar baits found no differences in the assemblage of fishes attracted to BRUVS (Dorman et al. 2012). At each site, a set of six BRUVS were deployed, separated by a minimum of $500 \mathrm{~m}$ and left to record for approximately $60 \mathrm{~min}$ on the seafloor (between the hours of 07:00 and 16:00 to avoid potential changes in behaviour of fishes under conditions of low light [Myers et al. 2016]). A total of 33 BRUVS (five $x$ set of six deployments) were deployed at Lighthouse Reef and 48 (eight $x$ set of six deployments) at San Sebastian Reef during the study (Table S1). The dataset from Bazaruto Island was a subset from a larger dataset, which was reduced to focus on the area in and around the notake area at Lighthouse Reef (Full set of deployments at https://globalarchive.org/geodata/data/campaign/get/590). [Please clarify how you get from 
a set of 6 BRUVS to a total of 30 BRUVS. Did you have five deployments of the set of six? Also, you have not cited Supplementary Table S2 in the text. Presumably it should be cited here, in which case it would become Table S1 and the current Table S1 would become Table S2.]

Where possible, deployments were made near randomly generated points created using a random point generator in ArcGIS ${ }^{\circledR}$ software by Esri. This was not always logistically possible, and in instances where it was impractical or hazardous, BRUVS were deployed on reef patches or contiguous reef as near as possible to the randomly generated points. This resulted in uneven sampling among different habitat types, with more deployments in sand habitat at Lighthouse Reef compared to San Sebastian Reef (30\% and 10\% respectively) and more deployments over reef habitat at San Sebastian compared to Lighthouse Reef (60\% and 39\% respectively). EventMeasure software (SeaGIS ${ }^{\mathrm{TM}}$ ) was used to identify and calculate the abundance of each fish species observed across the 81 samples. All fishes recorded on video were identified to species level where possible. The maximum number of individuals for each species viewed at any one time (MaxN; Priede et al. 1994) was recorded from viewing the footage and used as a measure of relative abundance averaged over a sixty-minute period, expressed as individuals per hour [check].

\section{Data processing}

In order to compare functional groups between the two sites, fishes were assigned to one of eight categories (herbivores, omnivores, browsers of sessile invertebrates, diurnal carnivores, nocturnal carnivores, piscivores, diurnal planktivores and nocturnal planktivores; see Supplementary Table S1) based on classifications used in previous studies (Hiatt and Strasberg 1960; Hobson 1974; Harmelin-Vivien 1979; Myers 1999) and completed using information on functional groups [check] from Vivien (1973), Parrish and Boland (2004), Rajasuriya (2013), Tickler (2015) and Fordyce (2016). In order to compare functional-group structure with other studies in the western Indian Ocean (WIO), the number of categories was reduced to three (herbivores, omnivores and carnivores). For these broader groupings, all categories except herbivores and omnivores were pooled into the carnivore group. Fishes were assigned to the target-fish group (Supplementary Table S1) based on information contained in Balidy et al. (2007), Claquin (2008), Doherty et al. (1950), Everett et al. (2008), and FAO (2007). [check edit]. [Why are these two references in a separate sentence? Why not just add them to the previous sentence?] Images of the habitat present in each BRUVS deployment were used to categorise deployments into one of three categories: 'reef', 'sand', or 'mixed' (both reef and sand) based on which contributed the highest percentage. When it was difficult to assign a representative habitat (i.e. where the distribution was close to 
$50 / 50$ ), it was designated as 'mixed'. Determination of habitat category was done by the same observer, to limit bias.

\section{Fish abundance modelling}

A multi-model approach using generalised linear models (GLM) with a negative binomial distribution was initially adopted to test our hypothesis [singular or plural?] relating to targeted fish abundance inside and outside of the BANP. [See comment at end of Introduction. You have not stated there what your hypotheses are, but you need to. However, as I understand it, you are not comparing simply 'inside the BANP' with 'outside the BANP'; instead you are comparing 'inside a no-take area within the BANP' with 'outside the BANP'. But then that raises the question of whether your Lighthouse Reef sampling site was inside or outside the no-take area.] Negative binomial GLMs were chosen over Poisson GLMs because of poor deviance explained (22.12 DE) and large overdispersion (43.01). Negative binomial GLM analyses were conducted using the ' $g$ lm.nb' function in the R package 'MASS' (Venables and Ripley 2002). To address any differences in deployment duration of BRUVS (range 57-87 mins), 'soak time' was used as an offset within the model structure. Four data points representing targeted fish exceeding 300 individuals per deployment [Is 'drop' synonymous with 'deployment'? Use consistent terminology.] were removed from the model dataset to avoid influencing model assumptions and fit (Zuur et al. 2009). Four deployments were also removed from the San Sebastian dataset due to these deployments landing in comparatively rare rocky habitat, and a further three deployments were removed from Lighthouse Reef for the same reason. Five models were fitted, including an intercept-only model, as well as single-term models with 'site', 'depth', or 'habitat', and a saturated model including all three variables. Models were then ranked using Akaike's information criterion weights corrected for small sample sizes (wAICc) (Burnham and Anderson 2002) and the model with the highest wAICc value was selected as the 'best model'. Variance partitioning was used to assess the effects of independent explanatory variables within the model structure. This procedure used the 'hier.part' package in $R$ (Walsh et al. 2013).

Differences in mean relative abundance of targeted species of fish between Lighthouse Reef and San Sebastian Reef, and among differing habitats, were estimated using partial residuals plots from the GLMs using the 'Visreg' package in R (Breheny and Burchett 2017[not in References]). Mean relative abundance was also calculated for all fish species found at each site. [See query in 'Study sites' section regarding whether San Sebastian Reef is in the Bazaruto Archipelago. Are you saying in this final sentence that a mean relative 
abundance per species was calculated for Lighthouse and San Sebastian reefs combined?]

\section{Analyses of fish community structure}

Species rarefaction curves recording the rate at which new species $(y)$ are added with extended sampling effort $(x)$ were used to compare the richness of fish species between sites (Thompson and Withers 2003). Curves that asymptote provide support that all species have been sampled, whereas curves that fail to asymptote suggest that an incomplete set of species have been observed.

Prior to conducting multivariate analyses, relative abundance was transformed using a common logarithm $(+1)$ to create Bray-Curtis similarity matrices. A logarithmic transformation was chosen because it ensured that contributions of uncommon genera were accounted for, while reducing the importance of dominant genera in the analysis (Clarke and Warwick 2001 [not in References]). All statistical tests used the software R (R Core Team 2019).[Use of $R$ itself should be cited as 'R Core Team (year)'. The Pinheiro reference is for the package 'nmle', specifically.]).To explore patterns in the community structure of fish at the level of individual deployments of BRUVS across all habitats sampled at Lighthouse Reef and San Sebastian Reef, the Bray-Curtis distance matrix derived from transformed values was subjected to hierarchical agglomerative clustering with group average linking (function 'hclust' from the package 'stats') and an associated similarity profiles test (function 'simprof' from the package 'clustsig'; Clarke et al. 2008). Similarity profiles were used to identify whether BRUVS from particular sites and habitats clustered together, and hence did not differ significantly in their species composition. This analysis was a permutation test that determined whether any significant group structure existed, within the samples, for which there was no a priori grouping hypothesis (Clarke et al. 2008). In addition to cluster analysis, a principal components analysis (PCA), using the function 'pco' in the package 'ecodist' (Goslee and Urban 2007), was used to examine differences in community structure between sites and habitats. The 'vf' function in this package was used to find the maximum correlation of the individual variables with the configuration of BRUVS deployments in ordination space.

\section{Results}

\section{Species rarefaction curves}

Species rarefaction curves for each location approached asymptotes, indicating that a large portion of available species were sampled by our study (Figure 2). [Deleted sentence duplicates final sentence of paragraph] Lighthouse Reef and San Sebastian Reef 
displayed similar curves, although there was a slight difference in the total number of species recorded (Figure 2). Both sites approached an asymptote, suggesting that, although some latent biodiversity was not described, the majority of fishes detectable by BRUVS deployments were recorded.

\section{Species richness}

We recorded a total of 16412 fishes, comprising 220 species and 49 families. Seven families represented more than half of the total number of species observed (54\%). These included 34 species in the Labridae, 21 Chaetodontidae, 18 Acanthuridae and 14 Serranidae and 11 species in each of the Carangidae, Lutjanidae and Scaridae (Supplementary Table S2). Mean species richness per hour at Lighthouse Reef was 25.81 species $h^{-1}$ (SE 3.44) and at San Sebastian Reef was 38.74 species $h^{-1}$ (SE 2.79). Overall, San Sebastian Reef had higher numbers of species than Lighthouse Reef (Supplementary Table S2) [This table does not show genera or families.]. When combining overall species richness across both sites, the greatest richness occurred over reef habitat $(n=213)$, followed by mixed habitat $(n=171)$, and then sand habitat $(n=81)$.

\section{Functional group structure}

[This paragraph duplicates all the information, including the percentages, contained in Figure 3. Repetition should be avoided, so please reduce the paragraph to summary statements only. However, please check that the percentages shown in Figure 3 are correct, because there are numerous discrepancies between the figure and the text, as shown below.] Using the most basic grouping of functional categories, $80 \%$ of the fish community at Lighthouse Reef was composed of carnivores, 7\% [Figure 3 shows 7\%] of omnivores, and 13\% [13\% in Figure 3] herbivores (Figure 3). Community composition was similar at San Sebastian Reef, consisting of 81\% carnivores, 8\% [8\% in Figure 3] omnivores, and $11 \%$ [11\% in Figure 3] herbivores (Figure 3). [Some disagreement in numbers with Supplementary Table S3, too.] Separation of fishes into finer-scale categories revealed that, at both sites, the largest number of species recorded by the BRUVS were diurnal carnivores, which were mostly labrids. Browsers of sessile invertebrates (Chaetodontidae), nocturnal carnivores (e.g. Lutjanidae) and herbivores (Acanthuridae and Scaridae) were also in comparable proportions at each site. In addition, the functional groups containing the fewest species at each site were similar (i.e. Omnivores such as Pomacentridae, piscivores such as Serranidae and Carcharhinidae, diurnal planktivores such as Caesionidae, and nocturnal planktivores such as Pempheridae). 


\section{Fish abundance in relation to habitat characteristics}

The effect of habitat variables on relative abundance of target fishes was examined using negative binomial generalised linear models (GLMs). The model that provided the top-ranked fit $($ WAICc $=0.97)$ and explained the greatest amount of deviance $(28.5 \% \mathrm{DE})$ for relative fish abundance included the explanatory variables habitat, depth, and site (Table 1). Variance partitioning of explanatory variables indicated that the $59 \%$ of the variance was explained by depth, which was followed by habitat at $26.5 \%$, and then site at $14.4 \%$ (Supplementary Figure S2 [Figures and tables should be introduced in numerical order. This should be renumbered as Figure S2]).

The mean relative abundance of all target species was 2.7 times greater at San Sebastian Reef (80.22 ind. $\mathrm{h}^{-1}$ [SE 18.00]) compared to Lighthouse Reef (29.70 ind. $\mathrm{h}^{-1}$ [SE 8.91]), and a similar pattern was observed for all species combined (target and non-target) (Lighthouse Reef 95.10 ind. $h^{-1}$ [SE 24.21]; San Sebastian Reef 219.12 ind. $h^{-1}$ [SE 33.12]). When accounting for habitat and depth effects on the relative abundance of targeted fish at each site, using the top-ranked model, there were still more than double the number of targeted fish at San Sebastian Reef compared to Lighthouse Reef (Figure 4a). Targeted fishes occurred in greater relative abundance in mixed and reef habitats, according to the model, a pattern that was consistent both at Lighthouse and San Sebastian reefs (Figure 4b). The latter reef consistently had greater relative abundance of target fishes across all habitats and depths (Figure $4 b$ [This should be ' $4 b$, c'. Figure $4 c$ does not include habitat.]).

The most common targeted species belonged to the carnivorous functional group and all occurred in higher relative abundance at San Sebastian Reef. These included Aprion virescens, Lutjanus gibbus, Thalassoma hebraicum and T. lunare (Figure 5a-d). In contrast, two of the most commonly targeted herbivores, Acanthurus tennenti and Scarus rubroviolaceus showed patterns of slightly increased relative abundance at Lighthouse Reef compared to San Sebastian (Figure 5e and f).

\section{Fish community composition}

The composition of fish communities showed some overlap between Lighthouse and San Sebastian reefs and varied among habitats (Figure 6; Supplementary Figure S3[Should be renumbered S3]). Communities at the two reefs had similar levels of complexity and diversity. Those at Lighthouse Reef were dominated by assemblages found in mixed habitats, whereas those at San Sebastian Reef were dominated by reef assemblages. There was considerable overlap in fish community composition between sites in reef and mixed habitats (Supplementary Figure S3[Should become S3]). The most complex and diverse communities 
of fishes were found in reef habitats, followed by mixed habitats and then sand habitats. PCA ordination suggested that there were two groupings of fish communities; (i) reef and mixed habitats; and (ii) sand habitats (Figure 6).

\section{Discussion}

The findings of our study provide preliminary estimates of relative abundance and diversity of species targeted by fishing at sites and across multiple habitats in southern Mozambique using a fishery-independent sampling technique. Total and targeted species richness and relative abundance were both greater at San Sebastian Reef than at Lighthouse Reef, a difference that was largely driven by localised variation in depth and habitat. The availability of optimal habitats, particularly reef areas, was better represented at San Sebastian Reef than at Lighthouse Reef. [Have you described anywhere in the Methods how depth and habitat differed at the two sites? This information seems to be missing.] Previous studies in the region have also found that benthic habitat can have a strong effect on patterns in fish density and assemblage structure (e.g. Currie et al. 2012; Osuka et al. 2018), and this variable can explain large proportions of variation in models (30-65\%) (Pinca et al. 2012; Russ et al. 2015, although see Hawkins et al. 2006). Higher numbers of fishes in reef habitats is likely a result of the numerous complex micro-habitats and the greater variety of food sources compared to those available in less-complex habitats (Gratwicke and Speight 2005). Reef size has also been shown to have a positive effect on the abundance and biomass of several species of predatory fish in protected areas of the WIO (Dames et al. 2019). Unfortunately, there were no detailed benthic habitat maps available for both of our sites and so we were unable to model the potential effects of reef size on relative abundance. However, we sampled reef structures that ran over a similar length of coastline at each site, albeit a slightly longer section at San Sebastian (Lighthouse Reef $=8.5 \mathrm{~km}$ and San Sebastian Reef $=10.5 \mathrm{~km}$ ). [Have you described/documented how reef size differed between your two sides?] Sandy habitats had the lowest community richness of fish in our study. [ls this documented in the Results?] This pattern of lower abundance in sandy habitats has also been noted by previous studies (e.g. Carpenter et al. 1981). In contrast, Samoilys et al. (2019) found no effect of habitat variables on fish assemblage in the WIO region; rather, geomorphology, exposure and fishing pressure drove patterns. Indeed, these factors probably contributed to the $14 \%$ of site variation in fish abundance in our models, after accounting for the influence of habitat type and depth.

Our findings provide some of the first estimates of targeted-reef-fish abundance for Mozambique using a fishery-independent assessment method, which is critical to ensure effective management of this resource. Our estimates of mean targeted-fish abundance varied 
between 29.70 ind. $\mathrm{h}^{-1}$ [SE 8.91] (Lighthouse Reef) and 80.22 ind. $\mathrm{h}^{-1}$ [SE 18.00] (San Sebastian Reef). It is unknown how this range compares to other areas within the WIO region, although some estimates exist for commonly targeted species. For example, $A$. virescens is a known target, particularly for recreational fishers, and was found in greater average abundance in our study (1-1.7 ind. $\mathrm{h}^{-1}$ ) than in other studies of protected areas in South Africa (0.6-0.9 ind. $\mathrm{h}^{-1}$ ) (Dames et al. 2019). In fact, the common species in our study ranged between mean abundances of 1 and $4.5 \mathrm{ind} . \mathrm{h}^{-1}$, which is high compared to estimates from other areas in the region where BRUVS were used [What method? BRUVS, or fisheryindependent assessment in general?] to assess the abundance of targeted reef fish such as members of the families Lutjanidae, Lethrinidae, and Serranidae. The study by Dames et al. (2019) found that the mean abundances of common targeted fish were all $<2.5$ ind. $\mathrm{h}^{-1}$ in protected zones of the iSimangaliso Wetland Marine Park in South Africa. Similarly, a study by Unsworth et al. (2015) in Palma Bay in northern Mozambique observed that species such as Lethrinus variegatus, Lutjanus ehrenbergii and Lutjanus kasmira ranged in average abundance between 0.4 and 0.66 ind. $\mathrm{h}^{-1}$. Furthermore, Unsworth et al. (2015) recorded an average total fish abundance of $30 \mathrm{ind} . \mathrm{h}^{-1}$, which was at the lower end of the range in our study $\left(30-80\right.$ ind. $\left.h^{-1}\right)$. Although it was not possible to draw a strict comparison between results from our study and those from studies at these other sites (i.e. in northern Mozambique and northern South Africa), our estimates for common species of targeted fish in the same general region (southwest Indian Ocean) provide some confidence that protective measures in the BANP and the isolation of San Sebastian from high-density human populations [In what way is it isolated? You need to mention isolation in the description of study sites in Methods.] are likely to be providing benefits for some targeted species at a local scale.

Our study observed 189 species on BRUVS within the BANP at Lighthouse Reef, which was considerably more than was observed with UVC (103 species) by Maggs et al. (2010). Baited video surveys have recorded a greater proportion of predatory species when compared to UVC (Langlois et al. 2006; Goetze et al. 2015). Species accumulation curves from our study suggest that the majority of the species richness at Lighthouse Reef that is detectable by BRUVS was captured by our sampling. It is also important to note that sampling by Maggs et al. (2010) was conducted on small patches of reef at Lighthouse Reef, and hence their study would not have covered as great an area as our study. At the scale of the southwest Indian Ocean, our sampling produced fewer species overall (220) than did other surveys of fish communities in the region (Supplementary Table S3, Figure S4), most of which used underwater visual census on outer reef slopes. These studies found that species richness ranged between 225 and 334 species per location. Interpretation of these comparisons should be made with caution, however, as BRUVS preferentially sample fishes attracted to bait, rather 
than the complete community (Harvey et al. 2007), and our study covered a different range of habitats and depths than the previous studies. A previous study found differences in species richness between sites outside BANP (Twelve-mile Reef) and sites inside BANP in the notake areas, but also among sites within the no-take areas (Maggs et al. 2010). [Text deleted because the information is contained in the next sentence.] Contrary to our findings of lower species richness within the BANP at Lighthouse Reef compared to outside the BANP at San Sebastian, Maggs et al (2010) observed that species richness in sites outside the BANP was usually lower than sites inside the BANP [It is this sentence, where you say 'contrary to our findings', that implies that you consider your Lighthouse Reef sampling site to be inside the no-take area.]. In addition, within the no-take areas, Maggs et al (2010) found that Two-Mile Reef had twice the number of species as the no-take area bordering Lighthouse Reef. Although we were unable to focus on fish communities at Two-Mile Reef in our study due to limited resources, abundance and community structure should be the focus of future work in this area.

Unequal proportions of the different categories of carnivores was one of the main differences in functional composition between the two sites in our study, with more nocturnal and diurnal carnivores and fewer browsers of sessile invertebrates at San Sebastian Reef than at Lighthouse Reef. This is important because diurnal and particularly nocturnal carnivores represent the majority of species targeted by fisheries in the region, in contrast to browsers of sessile invertebrates (Supplementary Table S1). Of the common species targeted by fisheries, carnivores were in higher relative abundance at San Sebastian Reef, while common herbivores were more abundant at Lighthouse Reef. This likely reflects differences in the availability of habitat at the two sites suitable for the differing foraging behaviour [check] and diets of these functional groups. [I have suggested the addition of 'behaviour' to clarify why (I think) you have included both 'foraging' and 'diets'.]

Fish community structure and diversity were comparable between sites although proportions of these groups differed in each. Cluster analysis identified that there was a large overlap between reef-fish assemblages and dominant clusters at San Sebastian Reef, which was due to the greater proportion of reef habitats sampled at San Sebastian than at Lighthouse Reef. [Again, did you present this information in Methods, i.e. re proportion of habitats sampled?] In contrast to our findings, previous work by Maggs et al. (2010) found that the notake areas inside the BANP at Two-Mile Reef and Lighthouse Reef had greater proportions of target species of carnivores ( $74 \%$ and $66 \%$, respectively) compared to Twelve-Mile Reef (63\% carnivores) outside the BANP. The functional-group structure of fish communities in our study was comparable with locations across the southwest Indian Ocean that had been surveyed 
using UVC (Supplementary Table S3), where carnivores comprised between 51 and $80 \%$ of the fish community.

One of the potential factors that might have led to fewer species, reduced abundance, and lower proportions of carnivores within Lighthouse Reef in the BANP compared to San Sebastian Reef could be lack of enforcement of reserve [This acronym would need to be defined. However, this is the only time that you refer to 'marine protected area'. Best to stick to terms that you have used previously.] regulations or differing human impacts at these two sites or in their vicinities (e.g. Cinner et al. 2018). Such impacts could include fishing effort, which might well be greater around Lighthouse Reef compared to San Sebastian Reef due to its close proximity to the coastal town of Vilanculos. Although the BANP was created in 1971, the first conservation and development plan was not implemented until 1989 [Development of the plan, or implementation of it?]. Furthermore, park boundaries and management were not originally well defined or structured. Park zone boundaries have undergone re-zoning through time (See MITUR 2002 and 2008; Diaz et al. 2016), which has helped to clarify the boundaries. [This reference is 12 years old, and hence cannot be referred to as 'today'. Also, in your description of your study site in the Methods, you say that the boundaries of the no-take area are not clear. Here you are saying that the boundaries of the BANP as a whole are not clear. Is that correct?]. Enforcement of park regulations was originally the responsibility of the warden (marine park ranger), whose role was limited to that of intermediary between tourism concessions and local populations (Claquin 2008). BANP management staff highlighted a need to improve the patrol level (MITUR 2002), which led to numerous private companies, NGOs, and institutions providing logistical support to the BANP in the form of a patrol boat and training (Diaz et al. 2016). [That was 18 years ago! No update? Even a personal communication?]

A nominal proportion of the variation in our model was attributed to other site-specific variables, which might include subtle localised habitat differences not adequately captured in our coarse habitat categories, or differing levels of protection from fishing practices. Enforcement and compliance with park regulations by fishers are common issues in marine reserves throughout the world (Bergseth et al. 2015). The performance of a marine reserve can be measured by how well it preserves density, biomass, size, and diversity of organisms as well as how it serves [check] human needs through time (Halpern 2003). Although we did not measure biomass or size of individual fish in our survey, lower relative abundance and diversity inside the park suggests that there is limited suitable habitat at Lighthouse Reef to support ['support'?] diverse fish communities. A few studies of marine reserves have found little or no difference in fish communities inside and outside of no-take areas (e.g. Advani et 
al. 2015; Cox et al. 2017), although instances where fish are significantly lower in abundance and diversity inside no-take areas are rare (e.g. Gilby et al. 2017). As with our study, Gilby et al. (2017) found that increased abundance of fish outside of reserves was largely driven by inadequate coverage of optimal habitats, which is an issue relating to reserve placement. If rezoning or expansion of no-take areas was to occur in the future, we recommend expansion to the south of current boundaries of Lighthouse Reef to include all reef habitat in the northeast section of Bazaruto Island. [Can you suggest what that depth might be? You refer in the Conclusions to the 'main reef complex'. At what depth is that?]

It is important to reiterate here that not all of the BANP is a no-take area; with less than $1 \%$ (1,100 ha) of overall park area encompassed by such areas ('Total Marine Protection Zones') (Diaz et al. 2016). In the remaining areas of the park, only specific fishing techniques are allowed in Multiple Use Zones (e.g. line fishing is permitted), and inhabitant rights have been established that allow residents within the park to harvest resources in specific zones (e.g. Zones of Use Limited to Local Communities (Diaz et al. 2016)). [lt is not clear what is meant by 'inhabitant rights'. In the description of your study sites, you refer to Mozambican fishers who do not live inside the BANP, but you do not refer to inhabitants of the BANP.]

\section{Conclusions}

Our findings provide a detailed assessment of fish communities at two sites along the southern Mozambique coastline and highlight that localised depth and habitat variables explained most of the differences in community abundance and diversity. The current suite of habitats encompassed by Lighthouse Reef within the BANP might not be appropriate for improving targeted-reef-fish stocks, if this becomes a park management priority. Furthermore, the Lighthouse Reef no-take area [Which is where you sampled?] currently provides protection only to fish in a small area on the northeast corner of Bazaruto Island, and does not include reef habitat to the south. [I think it would be useful to include this information about the main reef complex in your description of the study site.] The no-take zone here could be extended to include the entire reef complex to provide greater protection. In contrast, San Sebastian Reef, outside of the BANP, appears to have a greater reef area and has higher species richness and, most importantly, a higher abundance of all fishes and of targeted fishes than at Lighthouse Reef. Managers of the San Sebastian Coastal Reserve have considered extending the boundaries offshore onto this reef to create a no-take area. However, the implementation of a no-take area in the San Sebastian reserve would be even more difficult to manage and enforce than in the BANP, given the increased distance from the town of 
Vilanculos [Distance from where? Presumably this is what you refer to earlier as 'isolation'.] and more difficult access [Do you mean 'more difficult access'?]. Ongoing monitoring of fish communities and increasing the area of suitable target-reef-fish habitat and depth with no-take status within the park could provide more positive conservation benefits in the long-term. Incorporation of results from previous studies in the region, together with information about local habitat conditions and pressures, would assist in improved management of the BANP. However, the small size of the no-take area at Lighthouse Reef and incomplete coverage of all available coral reef habitat in the immediate vicinity provides additional justification for rezoning of boundaries [Please see earlier query about whether it is just the boundaries of the no-take area that are not clear or whether it is the boundaries of the whole BANP. This is not clear at the moment.].

Acknowledgements - Funding for this research was made available through Paul G Allen Philanthropies. This work is a publication of the Global FinPrint Project. Relevant permits for this work were acquired through the National Directorate of Conservation Areas in the Ministry of Land, Environmental and Rural Development. We would like to thank A Mason for assistance with video processing.

\section{ORCID}

Tonin Sancelme https://orcid.org/0000-0001-8548-7070

Jordan Goetze https://orcid.org/0000-0002-3090-9763

Sébastien Jaquemet https://orcid.org/0000-0003-4199-4657

Mark Meekan https://orcid.org/0000-0002-3067-9427

Anna Flam https://orcid.org/0000-0002-8264-6926

Alexandra Watts https://orcid.org/0000-0002-1251-1735

Conrad Speed https://orcid.org/0000-0003-3186-8710

\section{References}

Advani S, Rix LN, Aherne DM, Alwany MA, Bailey DM. 2015. Distance from a fishing community explains fish abundance in a no-take zone with weak compliance. PloS ONE 10: e0126098

Balidy HJ, Pacule HH, Guissamulo AT, Mafambissa MJ. 2007. Lista de peixes asociados aos tapetes de ervas marinhas em Inhassoro. Centro Desenvolvimento Sustentável Zonas Costeiras, Ministério Para a Coordenação da Acção Ambiental, Centro de Desenvolvimento Sustentável para as Zonas Costeiras. Praia de Xai-Xai: 19. [More information needed. What type of publication is this? Part of a report series? Please expand 'CDS-ZC'. Location of publisher?] 
Ballantine W, Langlois T. 2008. Marine reserves: the need for systems. Hydrobiologia 606: 35-44.

Belhabib D, Sumaila UR, Le Billon P. 2019. The fisheries of Africa: exploitation, policy, and maritime security trends. Marine Policy, 101, 80-92. [Volume? Pagination (or document number)?]

Bergseth BJ, Russ GR, Cinner JE. 2015. Measuring and monitoring compliance in no-take marine reserves. Fish and Fisheries 16: 240-258.

Bernard A, Götz A. 2012. Bait increases the precision in count data from remote underwater video for most subtidal reef fish in the warm-temperate Agulhas bioregion. Marine Ecology Progress Series 471: 235-252.

Bernard AT, Götz A, Parker D, Heyns ER, Halse SJ, Riddin NA et al. 2014. New possibilities for research on reef fish across the continental shelf of South Africa. South African Journal of Science 110: article no. a0079.

Breheny, P., and W. Burchett. 2017. Visualization of regression models using visreg. The R Journal 9:56-71.

Burnham KP, Anderson DR. 2002. Information and likelihood theory: a basis for model selection and inference. In: Burnham KP, Anderson DR (eds), Model selection and multimodel inference: a practical information-theoretic approach. New York: Springer. pp 49-97.

Caveen A, Polunin N, Gray T, Stead SM. 2015. Critique of the scientific evidence for fisheries benefits of MRs. In: Caveen A, Polunin N, Gray T, Stead SM (eds), The controversy over marine protected areas. Springer Briefs in Environmental Science. Cham, Switzerland: Springer. pp $51-80$.

Carpenter KE, Miclat RI, Albaladejo VD. 1978. The influence of substrate structure on the local abundance and diversity of Philippine reef fishes. Philippine Journal of Fisheries (Philippines) 16(2): 1-17. [Please check reference information. A paper with the same title and authors was published in 1978 in the Philippine Journal of Fisheries 16(2): 1-17.]

Chabanet P, Bigot L, Nicet J-B, Durville P, Massé L, Mulochau T et al. 2016. Coral reef monitoring in the lles Eparses, Mozambique Channel (2011-2013). Acta Oecologica 72: 62-71.

[Not cited in the text] 
Cinner JE, Maire E, Huchery C, MacNeil MA, Graham NA, Mora C et al. 2018. Gravity of human impacts mediates coral reef conservation gains. Proceedings of the National Academy of Sciences 115: E6116-E6125.

Claquin B. 2008. Approche culturelle des communautés de pêcheurs traditionnels et mise en tourisme des îles du Mozambique. PhD[What degree, MSc or PhD?] Thesis, University of La Réunion, La Réunion.

Clarke, K. R., and R. Warwick. 2001. Change in marine communities. An approach to statistical analysis and interpretation.

Clarke KR, Somerfield PJ, Gorley RN. 2008. Testing of null hypotheses in exploratory community analyses: similarity profiles and biota-environment linkage. Journal of experimental marine biology and ecology, 366(1-2), 56-69 [A 2008 reference cannot be 'in' a 2001 reference. Please check details of Clarke et al. 2008. Also, I think that you have cited Clarke and Warwick (2001) independently in the text, so that needs to included as a separate reference.]

Colton MA, Swearer SE. 2010. A comparison of two survey methods: differences between underwater visual census and baited remote underwater video. Marine Ecology Progress Series 400: 1936.

Cox C, Valdivia A, McField M, Castillo K, Bruno JF. 2017. Establishment of marine protected areas alone does not restore coral reef communities in Belize. Marine Ecology Progress Series 563: 65-79.

Currie J, Sink K, Le Noury P, Branch G. 2012. Comparing fish communities in sanctuaries, partly protected areas and open-access reefs in South-East Africa. African Journal of Marine Science 34: 269-281.

Dames V, Bernard B, Floros C, Mann B, Speed CW, Maggs J et al. 2019. Zonation and reef size significantly influence fish population structure in an established marine protected area, iSimangaliso Wetland Park, South Africa. Ocean and Coastal Management, 105040. [Volume number? Pagination or article number?]

De Vos L, Götz A, Winker H, Attwood C. 2014. Optimal BRUVs (baited remote underwater video system) survey design for reef fish monitoring in the Stilbaai Marine Protected Area. African Journal of Marine Science 36: 1-10.

Diaz, P., L. D. Luis, M. Mafambissa, A. E. Uetimane, P. D. Madeira, E. M. Chambal, F. S. Gubudo, J. B. Zibane, and N. V. F. LIBERATO. 2016. Parque Nacional do Arquipélago de Bazaruto 
(PNAB). Plano de Maneio 2016 - 2025 de uma Área de Conservação Marinha, Província de Inhambane, Moçambique. EIA \& Services, Lda. (Projectos, Consultoria e Auditoria Ambiental). Administração Nacional das Áreas de Conservação (ANAC), Ministério da Terra, Ambiente e Desenvolvimento Rural (MITADER), Cidade de Maputo.

Doherty B, McBride MM, Brito AJ, Le Manach F, Sousa L, Chauca I, Zeller D. 1950. Marine fisheries in Mozambique: catches updated to 2010 and taxonomic disaggregation. In: Le Manach F, Pauly D (eds), Fisheries catch reconstructions in the Western Indian Ocean 1950-2010. Fisheries Centre Research Reports, vol. 23, no. 2. Vancouver: University of British Columbia. pp 67-81.

Dorman SR, Harvey ES, Newman SJ. 2012. Bait effects in sampling coral reef fish assemblages with stereo-BRUVs. PLoS ONE 7: e41538.

Everett BI, van der Elst R, Schleyer MH (eds). 2008. A natural history of the Bazaruto Archipelago, Mozambique. Special Publication No. 8. Durban: Oceanographic Research Institute.

FAO (United Nations Food and Agriculture Organization). 2007. National fishery sector overview: The Republic of Mozambique. Rome: FAO.

Fordyce AJ. 2016. Reef fish communities of Praia do Tofo, Mozambique, and the need for best practice management. PeerJ Preprints 4: e23891.

Gilby BL, Olds AD, Yabsley NA, Connolly RM, Maxwell PS, Schlacher TA. 2017. Enhancing the performance of marine reserves in estuaries: just add water. Biological Conservation 210: 1-7.

Goetze JS, Jupiter SD, Langlois TJ, Wilson SK, Harvey ES, Bond T, Naisilisili W. 2015. Diver operated video most accurately detects the impacts of fishing within periodically harvested closures. Journal of Experimental Marine Biology and Ecology 462: 74-82.

Goslee SC, Urban DL. 2007. The ecodist package for dissimilarity-based analysis of ecological data. Journal of Statistical Software 22: 1-19.

Gratwicke B, Speight MR. 2005. The relationship between fish species richness, abundance and habitat complexity in a range of shallow tropical marine habitats. Journal of Fish Biology 66: 650-667.

Halpern BA. 2003. The impact of marine reserves: do reserves work and does reserve size matter? Ecological Applications 13: S117-S137.

Harmelin-Vivien M. 1979 Ichthyofaune des recifs coralliens de Tulear (Madagascar): ecologie et relations trophiques. PhD[MSc or PhD?] Thesis, University of Aix, France. 
Harvey ES, Cappo M, Butler JJ, Hall N, Kendrick GA. 2007. Bait attraction affects the performance of remote underwater video stations in assessment of demersal fish community structure. Marine Ecology Progress Series 350: 245-254.

Hawkins JP, Roberts CM, Dytham C, Schelten C, Nugues MM. 2006. Effects of habitat characteristics and sedimentation on performance of marine reserves in St. Lucia. Biological Conservation 127: 487-499.

Heyns-Veale E, Bernard A, Richoux N, Parker D, Langlois T, Harvey E, Götz A. 2016. Depth and habitat determine assemblage structure of South Africa's warm-temperate reef fish. Marine Biology 163: 158.

Hiatt RW, Strasberg D. 1960. Ecological relationships of the fish fauna on coral reefs of the Marshall Islands. Ecological Monographs 30: 65-127.

Hobson ES. 1974. Feeding relationships of teleostean fishes on coral reefs in Kona, Hawaii. Fisheries Bulletin 72: 915-1031.

Kaunda-Arara B, Rose GA, Muchiri MS, Kaka R. 2003. Long-term trends in coral reef fish yields and exploitation rates of commercial species from coastal Kenya. Western Indian Ocean Journal of Marine Science 2: 105-116.

Langlois T, Chabanet P, Pelletier D, Harvey E. 2006. Baited underwater video for assessing reef fish populations in marine reserves. SPC Fisheries Newsletter No. 118. Noumea, New Caledonia: Pacific Community. pp 53-57.

Langlois TJ, Fitzpatrick BR, Fairclough DV, Wakefield CB, Hesp SA, McLean DL et al. 2012. Similarities between line fishing and baited stereovideo estimations of length-frequency: novel application of kernel density estimates. PLOS ONE 7: e45973.

MacNeil MA, Graham NA, Cinner JE, Wilson SK, Williams ID, Maina J et al. 2015. Recovery potential of the world's coral reef fishes. Nature 520: 341.

Maggs JQ, Floros C, Pereira MA, Schleyer MH. 2010. Rapid visual assessment of fish communities on selected reefs in the Bazaruto Archipelago. Western Indian Ocean Journal of Marine Science 9: 115-134.

McClanahan T, Arthur R. 2001. The effect of marine reserves and habitat on populations of East African coral reef fishes. Ecological Applications 11: 559-569. 
McClanahan TR. 1999. Is there a future for coral reef parks in poor tropical countries? Coral Reefs 18: 321-325.

McClanahan, T. R., N. A. Graham, M. A. MacNeil, N. A. Muthiga, J. E. Cinner, J. H. Bruggemann, and S. K. Wilson. 2011. Critical thresholds and tangible targets for ecosystem-based management of coral reef fisheries. Proceedings of the National Academy of Sciences 108:17230-17233.

McClanahan TR, Jadot C. 2017. Managing coral reef fish community biomass is a priority for biodiversity conservation in Madagascar. Marine Ecology Progress Series 580: 169-190.

McClanahan TR, Kaunda-Arara B. 1996. Fishery recovery in a coral-reef marine park and its effect on the adjacent fishery. Conservation Biology 10: 1187-1199.

McClanahan T, Muthigab N, Kamukuruc A, Machanod H, Kiamboa R. 1999. The effects of marine parks and fishing on coral reefs of northern Tanzania. Biological Conservation 89: 161-182.

McClanahan TR, Graham NA, Calnan JM, MacNeil MA. 2007. Toward pristine biomass: reef fish recovery in coral reef marine protected areas in Kenya. Ecological Applications 17: 1055-1067.

MITUR (Mozambique Ministry of Tourism). 2002. Plano de maneio: Parque Nacional do Arquipélago do Bazaruto 2002-2005. Maputo, República de Moçambique: MITUR.

MITUR (Mozambique Ministry of Tourism). 2008. Plano de maneio: Parque Nacional do Arquipélago do Bazaruto 2008-2012. Maputo, República de Moçambique: MITUR.

Myers EM, Harvey ES, Saunders BJ, Travers MJ. 2016. Fine-scale patterns in the day, night and crepuscular composition of a temperate reef fish assemblage. Marine Ecology 37: 668-678.

Myers RF. 1999. Micronesian reef fishes: a comprehensive guide to the coral reef fishes of Micronesia (3rd edn). Barrigada, Guam: Coral Graphics.

Osuka K, Kochzius M, Vanreusel A, Obura D, Samoilys M. 2018. Linkage between fish functional groups and coral reef benthic habitat composition in the Western Indian Ocean. Journal of the Marine Biological Association of the United Kingdom 98: 387-400.

Parrish FA, Boland RC. 2004. Habitat and reef-fish assemblages of banks in the Northwestern Hawaiian Islands. Marine Biology 144: 1065-1073. 
Pereira MA. 2000. A review on the ecology, exploitation and conservation of reef fish resources in Mozambique. Paper presented at the 2nd National Conference on Coastal Zones Research, Maputo, 27-29 September 2000.

Pinca S, Kronen M, Magron F, McArdle B, Vigliola L, Kulbicki M, Andréfouët S. 2012. Relative importance of habitat and fishing in influencing reef fish communities across seventeen Pacific Island Countries and Territories. Fish and Fisheries 13: 361-379.

Priede IG, Ragley PM, Smith KL. 1994. Seasonal change in activity of abyssal demersal scavenging grenadiers Coryphaenoides (Nematonums) armatus in the eastern North Pacific Ocean. Limnology and Oceanography 39: 279-285.

Rajasuriya A. 2013. Field guide to reef fishes of Sri Lanka, vols 1 and 2. Colombo: IUCN Sri Lanka Office.

R Core Team. 2019. A language and environment for statistical computing. R Foundation for Statistical Computing, Vienna, Austria.

Roberson L, Winker H, Attwood C, De Vos L, Sanguinetti C, Götz A. 2015. First survey of fishes in the Betty's Bay Marine Protected Area along South Africa's temperate south-west coast. African Journal of Marine Science 37: 543-556.

Roberts CM, Polunin NV. 1991. Are marine reserves effective in management of reef fisheries? Reviews in Fish Biology and Fisheries 1: 65-91.

Russ GR. 1991. Coral reef fisheries: effects and yields. In: Sale PF (ed.), The ecology of fishes on coral reefs. San Diego: Academic Press. pp 601-635.

Russ GR, Miller KI, Rizzari JR, Alcala AC. 2015. Long-term no-take marine reserve and benthic habitat effects on coral reef fishes. Marine Ecology Progress Series 529: 233-248.

Samoilys MA, Osuka K, Maina GW, Obura DO. 2017. Artisanal fisheries on Kenya's coral reefs: decadal trends reveal management needs. Fisheries Research 186: 177-191.

Samoilys MA, Halford A, Osuka K. 2019. Disentangling drivers of the abundance of coral reef fishes in the Western Indian Ocean. Ecology and Evolution 2019: 1-19.

Santos J. 2008. O papel da administração pesqueira na gestão do subsector artesanal em Moçambique: o presente e modelos para o futuro, Notas Técnicas DNAP. Maputo, Moçambique: Direção Nacional de Administração Pesqueira - Ministério das Pescas. 
Teh LS, Teh LC, Sumaila UR. 2013. A global estimate of the number of coral reef fishers. PLoS ONE 8: e65397.

Thompson GG, Withers PC. 2003. Effect of species richness and relative abundance on the shape of the species accumulation curve. Austral Ecology 28: 355-360.

Tickler DM. 2015. Nuanced differences in shark assemblages in protected and fished locations and drivers of their habitat use: implications for conservation. MSc[MSc or PhD?] Thesis, University of Western Australia, Australia.

Tuda PM, Wolff M. 2015. Evolving trends in the Kenyan artisanal reef fishery and its implications for fisheries management. Ocean and Coastal Management 104: 36-44.

Unsworth RK, Jones B, West A. 2015. Baseline assessment of fish assemblages of Palma Bay, Mozambique. Final report to MacAlister Elliott and Partners Ltd (MEP) Worldwide Fishery Consultants, produced by Aquatic Environmental Research Ltd, Spinoff of Swansea Innovations, Swansea University. [If MEP was the client, what company did Unsworth et al. represent, and where was it located? If MEP were the consultants who prepared the report, who was the client and where were they located?]

van der Elst RP, Afonso PS. 2008. Fish and fisheries. In: Everett BI, van der Elst RP, Schleyer MH (eds), A Natural History of Bazaruto Archipelago, Mozambique. Special Publication No. 8. Durban: Oceanographic Research Institute. pp 93-109.

Venables WN, Ripley BD. 2002. Random and mixed effects. In: Venables WN, Ripley BD (eds), Modern applied statistics with S. New York: Springer. pp 271-300.

Vivien ML. 1973. Régimes et comportements alimentaires de quelques poissons des récifs coralliens de Tuléar (Madagascar). La Revue d'Écologie (La Terre et la vie). Société Nationale de Protection de la Nature et d'Acclimatation de France. [Reference incomplete. What type of reference is this? Location and name of publisher?]

Walsh C, MacNally R, Walsh MC. 2013. The hier.part package. Hierarchical partitioning. $R$ project for statistical computing. Available at https://cran.r-project.org/web/packages/hier.part/index.html. [Please provide full, working URL for this package, and check all reference details.]

Watson DL, Harvey ES, Anderson MJ, Kendrick GA. 2005. A comparison of temperate reef fish assemblages recorded by three underwater stereo-video techniques. Marine Biology 148: 415425. 
Wells S, Ray GC, Gjerde KM, White AT, Muthiga N, Bezaury Creel JE, Kelleher G. 2016. Building the future of MPAs-lessons from history. Aquatic Conservation: Marine and Freshwater Ecosystems 26(Supplement 2): 101-125.

Wilhelm TA, Sheppard CR, Sheppard AL, Gaymer CF, Parks J, Wagner D, Lewis N. 2014. Large marine protected areas-advantages and challenges of going big. Aquatic Conservation: Marine and Freshwater Ecosystems 24(Supplement 2): 24-30.

Zuur A, leno EN, Walker N, Saveliev AA, Smith GM. 2009. Mixed effects models and extensions in ecology with R. Springer, Berlin [Location?].

\section{Figure legends}

Figure 1: Bazaruto Archipelago National Park (BANP) in southern Mozambique, showing the park boundary (solid black line) [Not dashed in figure] and positions of deployments of baited remote underwater video stations (white dots) at two sites: (a) Lighthouse Reef and (b) San Sebastian Reef. Lighthouse Reef is inside the BANP, in which fishing activities are restricted, whereas San Sebastian Reef is outside the BANP and is open to all fishing beyond the immediate shoreline. The boundary of the no-take area or 'Total Marine Protection Zone' at Lighthouse Reef (solid white line) extends offshore to include the main reef complex (See Diaz et al. 2016). All fishing activities are prohibited inside the no-take area. [Please check edits] [Source of images in (a) and (b)?] 


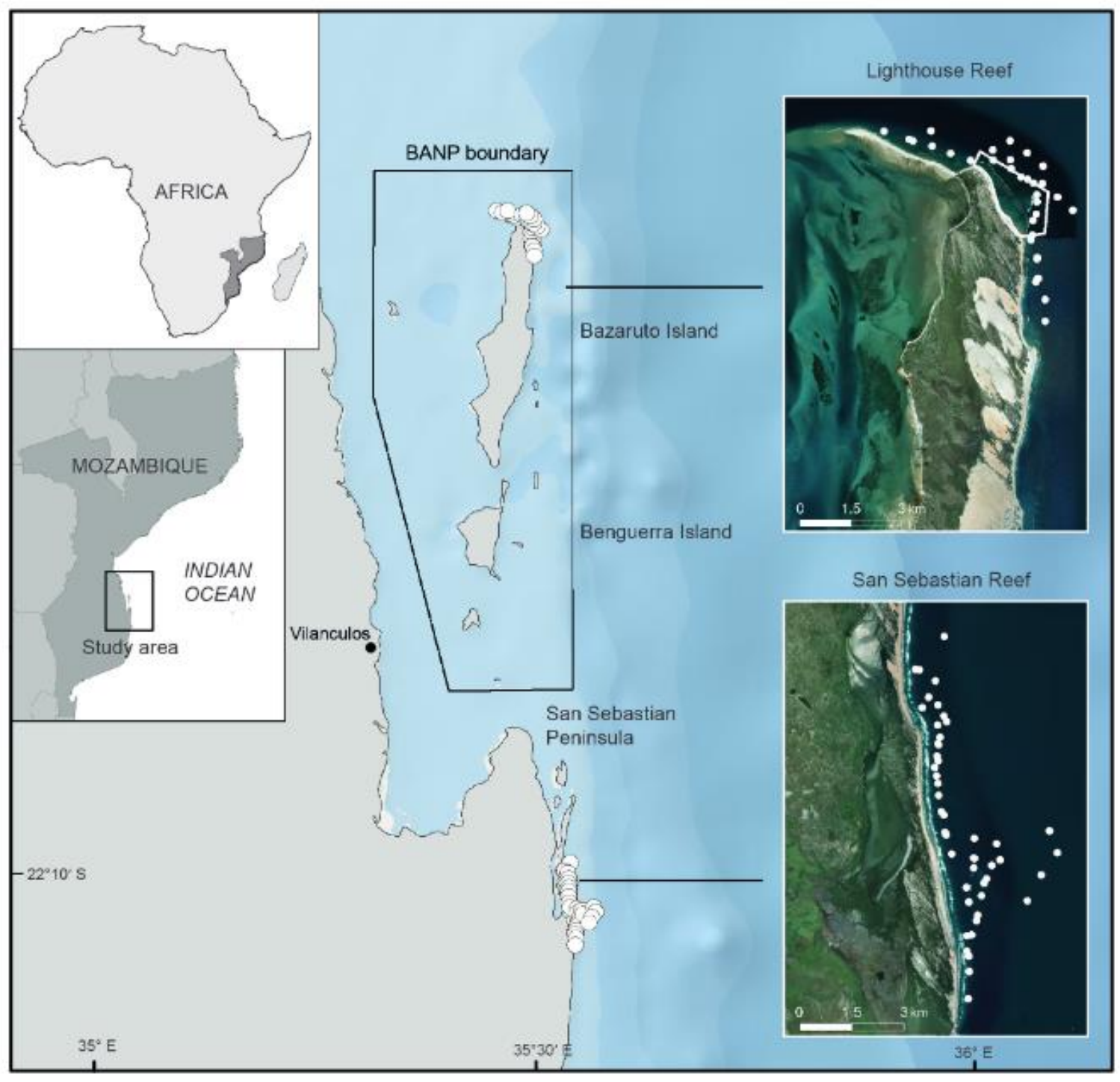

Figure 2: Species rarefaction curves for San Sebastian Reef and Lighthouse Reef, central Mozambique, in relation to the number of baited remote underwater video stations (BRUVS) deployed. Inset shows schematic of BRUVs (see also Supplementary Figure S1)

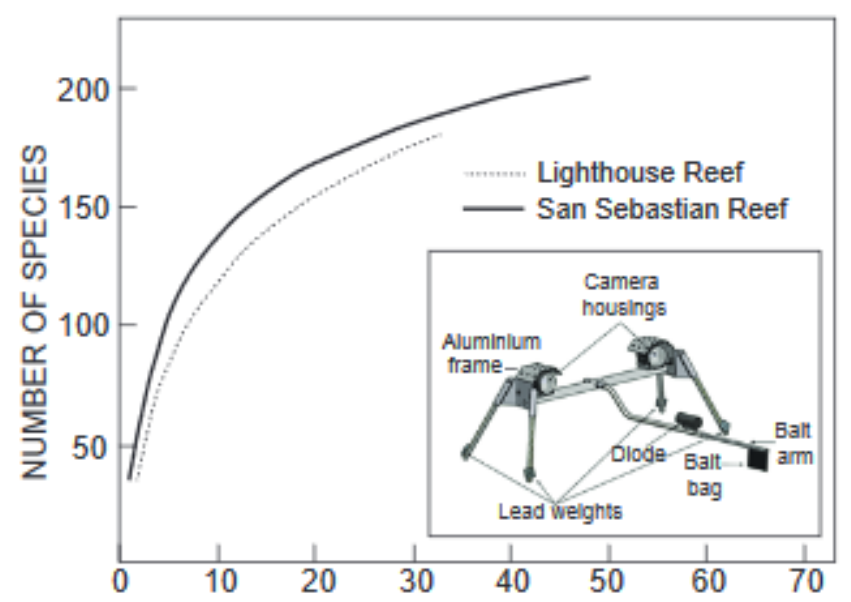


Figure 3: Overall functional structure of reef-fish communities at the two sites investigated using baited remote underwater video stations: (a) Lighthouse Reef and (b) San Sebastian Reef

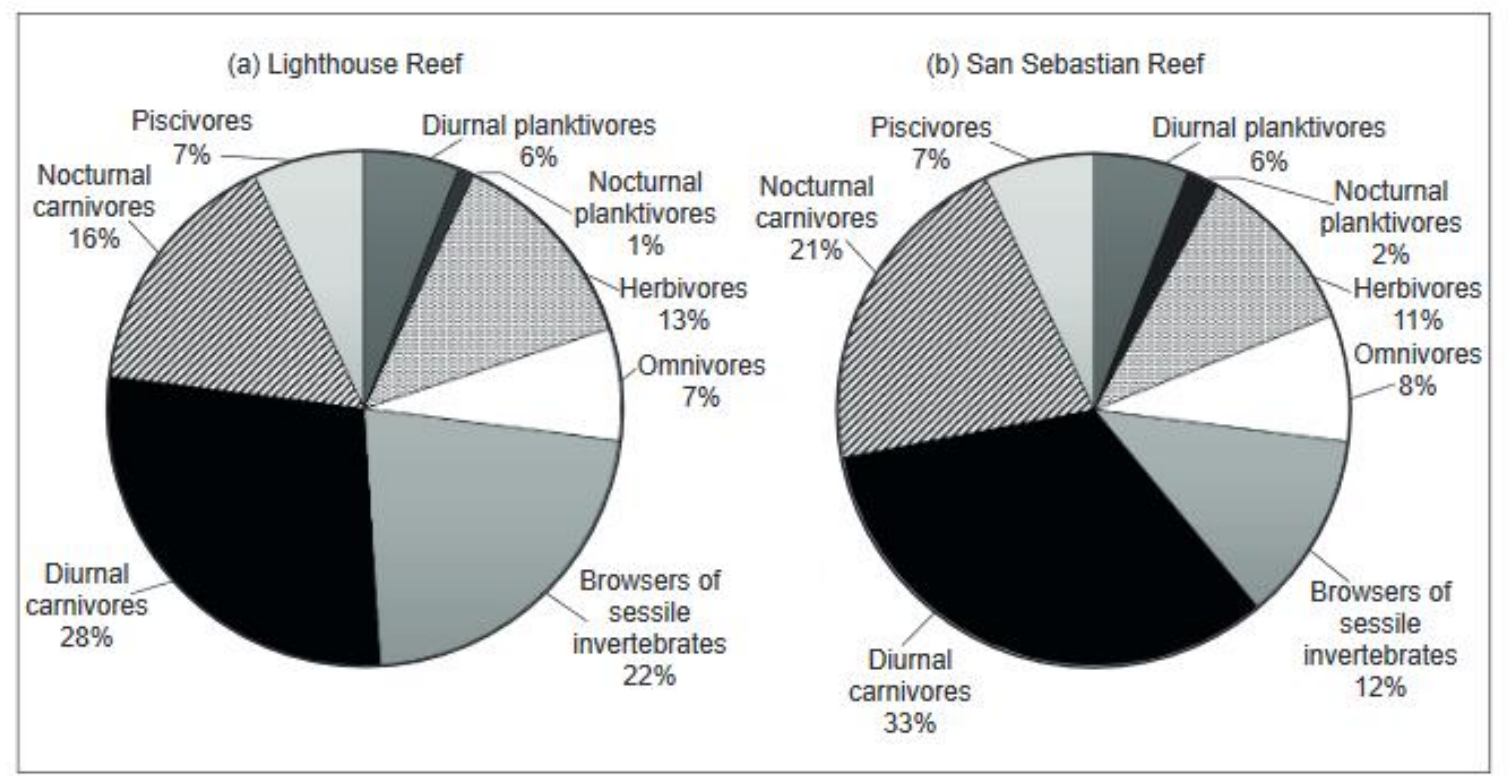

Figure 4: Partial residual plots relative to the independent variable (mean MaxN of targeted fishes [Does the $y$-axis have units? ind. $\mathrm{h}^{-1}$ ?]) in the top-ranked negative binomial generalised linear model, which included: (a) site; (b) habitat type; and (c) depth. Bold line represents the fitted line (predicted MaxN values) and grey shaded areas represent the 95\% confidence intervals [When you say the fitted line, do you mean the value of MaxN predicted by the model? Might that be more informative wording?]
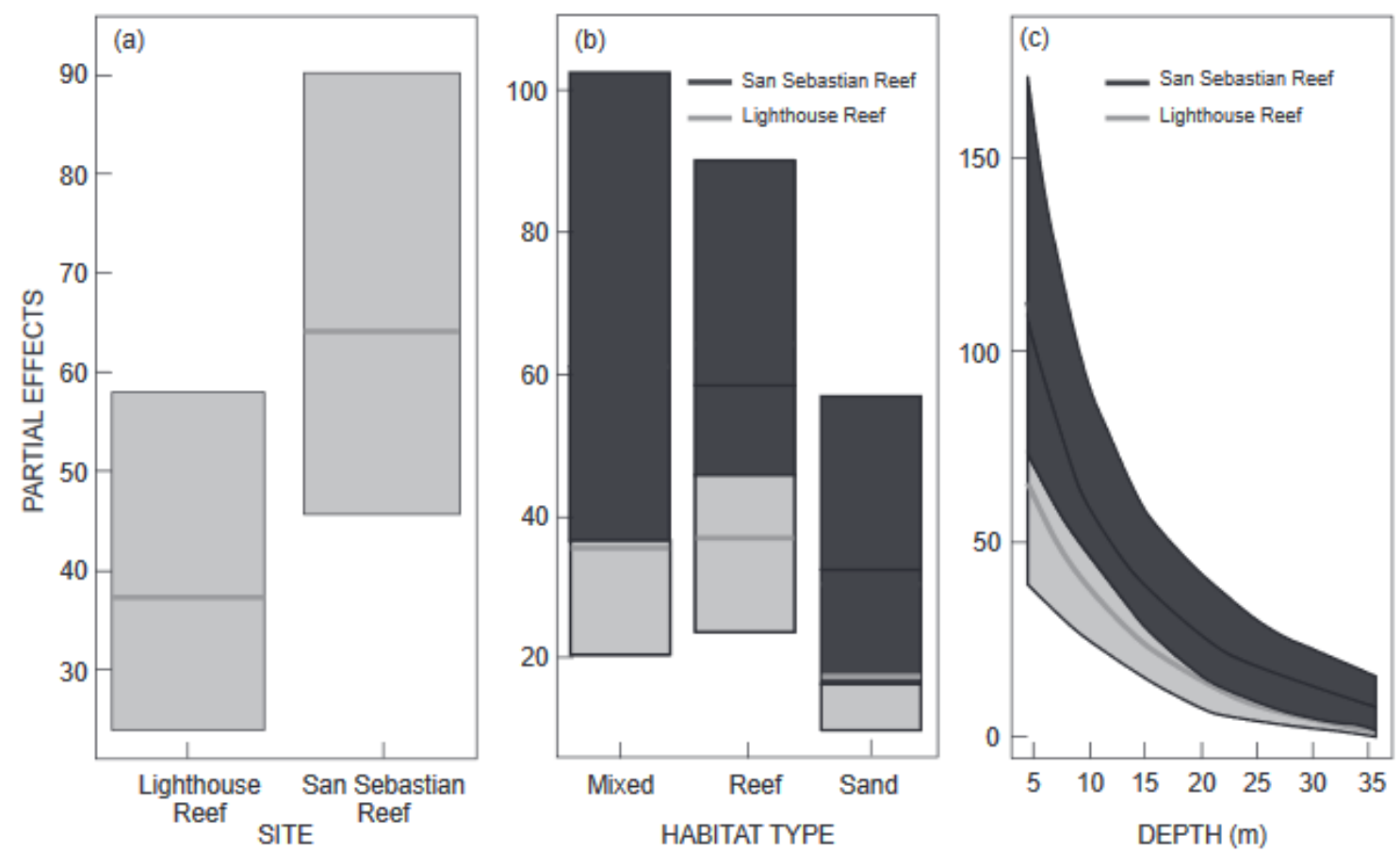
Figure 5: The six most common and abundant [Please explain the difference between 'common' and 'abundant'. Also, please clarify the name of the $y$-axis variable, and also the units. Would it be 'Mean MaxN (ind. $\mathrm{h}^{-1}$ )?] target species observed on baited remote underwater video stations (BRUVS) in southern Mozambique. These were (a) Aprion virescens, (b) Lutjanus gibbus, (c) Thalassoma herbraicum, (d) Thalassoma lunare, (e) Acanthurus tennenti and (f) Scarus rubroviolaceous. These species occurred in $>40 \%$ of all deployments combined [at both sites?]
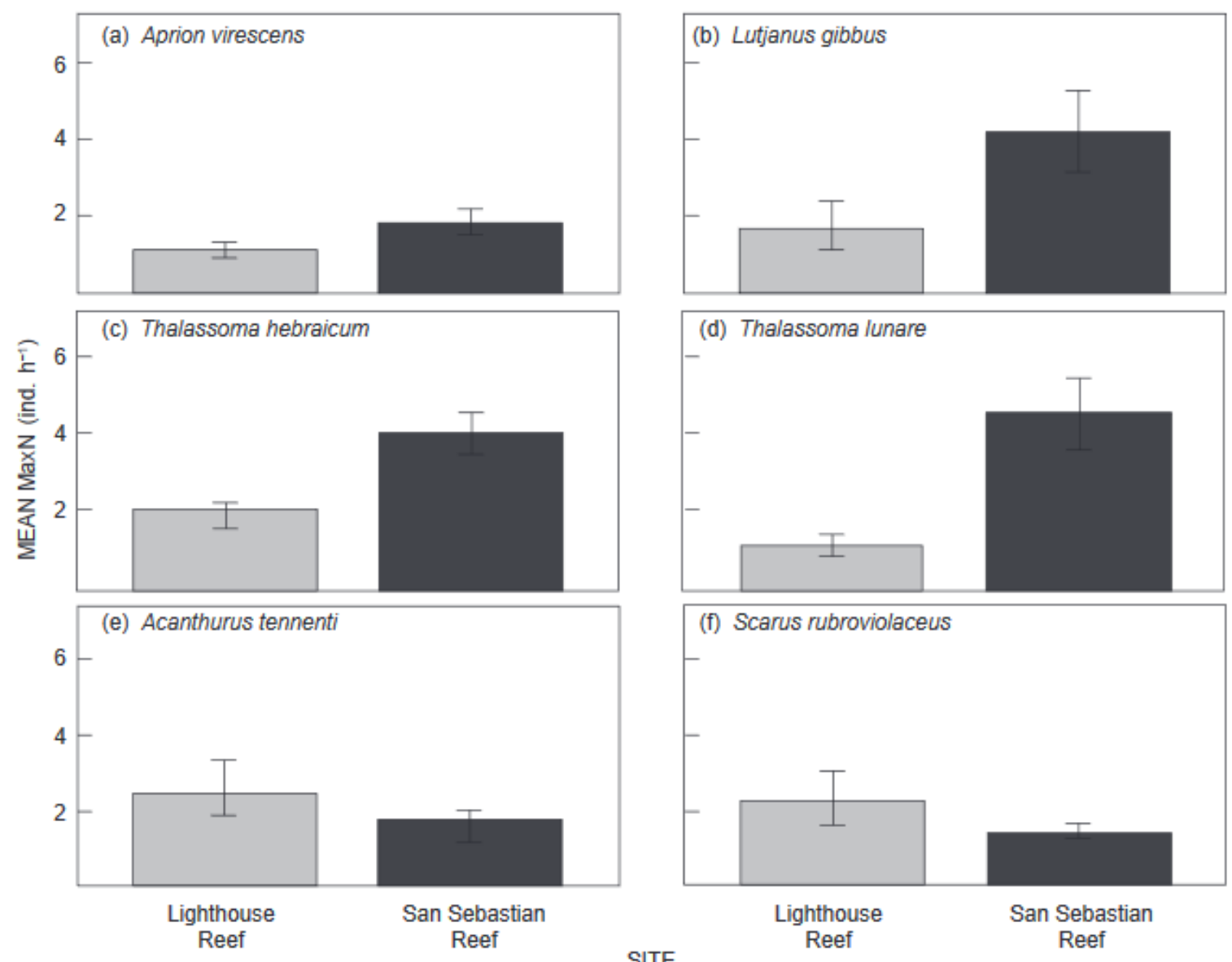

Figure 6: PCO ordination showing the fish community structure recorded at all baited remote underwater video stations, based on (a) site (San Sebastian and Lighthouse reefs), and (b) habitat 


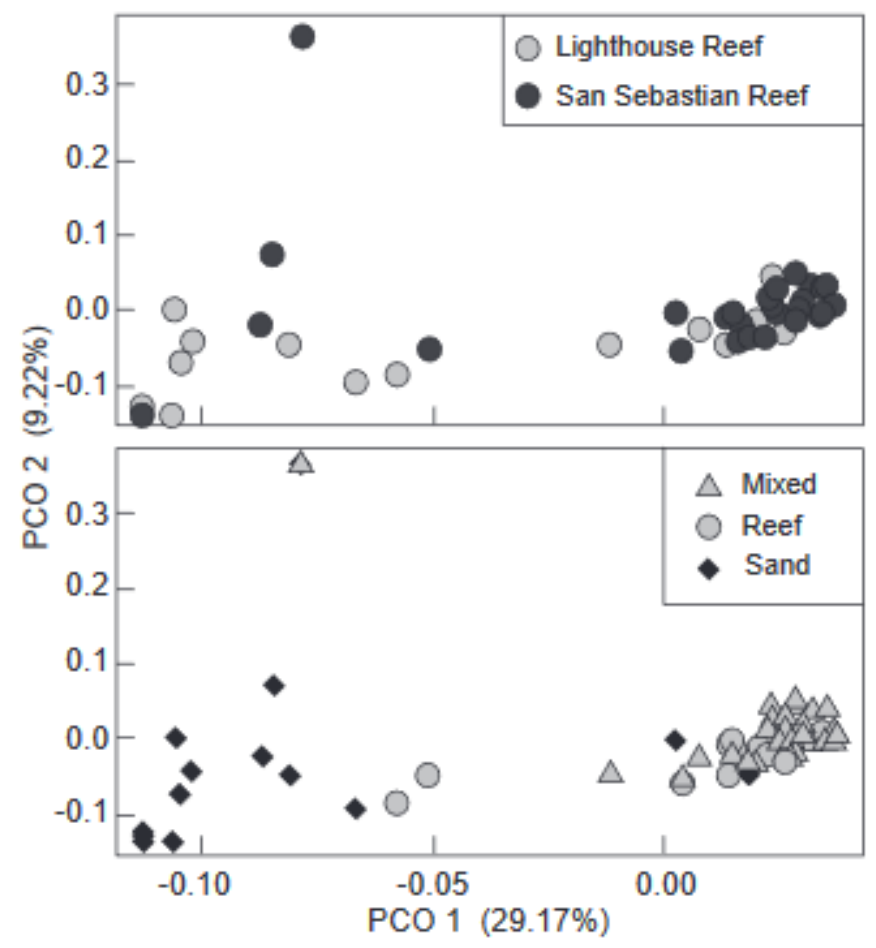


Table 1: Summary results of negative binomial generalised linear models used to test for effects of site [This is called 'Site' in the text and the table. Should be consistent], habitat, and depth variables on the MaxN of targeted fish recorded by baited remote underwater video stations (BRUVS) in southern Mozambique. The top-ranked model is highlighted in bold font [What is ' $K$ '?]

\begin{tabular}{lccccc}
\hline Model & $K$ & LogLik & AICc & $\Delta$ AICc & wAICc \\
\hline Site + Habitat + Depth & $\mathbf{5}$ & $\mathbf{- 3 2 0 . 2 8}$ & $\mathbf{6 5 1 . 4 9}$ & $\mathbf{0}$ & $\mathbf{0 . 9 7}$ \\
Depth & 3 & -326.2 & 658.76 & 7.27 & 0.03 \\
Habitat & 4 & -331.12 & 670.86 & 19.38 & 0 \\
Site & 3 & -333.31 & 672.99 & 21.5 & 0 \\
Intercept & 2 & -334.92 & 674.02 & 22.53 & 0 \\
\hline
\end{tabular}




\section{Supplementary material}

Table S1: List of all deployments of baited remote underwater video stations at Lighthouse and San Sebastian reefs, southern Mozambique, during August 2016

\begin{tabular}{|c|c|c|c|c|c|c|}
\hline Deployment & Date & Latitude (오) & Longitude ( $\left.{ }^{\circ} \mathrm{E}\right)$ & $\operatorname{Depth}(\mathrm{m})$ & Soak time & Reef \\
\hline CMBAZ_037 & $12-08-2016$ & -21.543613 & 35.497866 & 9.1 & 64 & Lighthouse \\
\hline CMBAZ_038 & $12-08-2016$ & -21.537923 & 35.497562 & 8.9 & 64 & Lighthouse \\
\hline CMBAZ_039 & $12-08-2016$ & -21.531871 & 35.496314 & 9 & 62 & Lighthouse \\
\hline CMBAZ_040 & $12-08-2016$ & -21.526161 & 35.497324 & 11.4 & 61 & Lighthouse \\
\hline CMBAZ_041 & $12-08-2016$ & -21.520927 & 35.497491 & 8.7 & 63 & Lighthouse \\
\hline CMBAZ_042 & $12-08-2016$ & -21.5167 & 35.495038 & 12.2 & 61 & Lighthouse \\
\hline CMBAZ_043 & $12-08-2016$ & -21.513809 & 35.490626 & 15.7 & 63 & Lighthouse \\
\hline CMBAZ_044 & $12-08-2016$ & -21.511632 & 35.485889 & 9.4 & 65 & Lighthouse \\
\hline CMBAZ_045 & $12-08-2016$ & -21.511643 & 35.479827 & 4.2 & 65 & Lighthouse \\
\hline CMBAZ_046 & $12-08-2016$ & -21.509738 & 35.474485 & 5.1 & 67 & Lighthouse \\
\hline CMBAZ_047 & $12-08-2016$ & -21.50772 & 35.469592 & 4.3 & 67 & Lighthouse \\
\hline CMBAZ_048 & $12-08-2016$ & 35.464442 & -21.506327 & 5.8 & 67 & Lighthouse \\
\hline CMBAZ_049 & $12-08-2016$ & -21.503732 & 35.456768 & 5.8 & 69 & Lighthouse \\
\hline CMBAZ_050 & $12-08-2016$ & 35.463431 & -21.505907 & 5.9 & 66 & Lighthouse \\
\hline CMBAZ_051 & $12-08-2016$ & -21.503619 & 35.46931 & 21 & 66 & Lighthouse \\
\hline CMBAZ_052 & $12-08-2016$ & -21.508848 & 35.48576 & 25 & 60 & Lighthouse \\
\hline CMBAZ_053 & $12-08-2016$ & -21.511495 & 35.490411 & 14.6 & 70 & Lighthouse \\
\hline CMBAZ_054 & $12-08-2016$ & -21.51617 & 35.49327 & 13.7 & 57 & Lighthouse \\
\hline CMBAZ_055 & $12-08-2016$ & -21.543781 & 35.497515 & 9.8 & 60 & Lighthouse \\
\hline CMBAZ_056 & $12-08-2016$ & -21.538299 & 35.497525 & 9.2 & 62 & Lighthouse \\
\hline CMBAZ_057 & $12-08-2016$ & -21.533159 & 35.495939 & 7 & 63 & Lighthouse \\
\hline CMBAZ_058 & $12-08-2016$ & 35.496427 & -21.527914 & 5.7 & 62 & Lighthouse \\
\hline CMBAZ_059 & $12-08-2016$ & -21.522838 & 35.497534 & 8.7 & 62 & Lighthouse \\
\hline CMBAZ_060 & $12-08-2016$ & -21.517732 & 35.496564 & 10.1 & 62 & Lighthouse \\
\hline CMBAZ_061 & $13-08-2016$ & -21.525113 & 35.50705 & 30.8 & 67 & Lighthouse \\
\hline CMBAZ_062 & $13-08-2016$ & -21.521549 & 35.502966 & 27.9 & 67 & Lighthouse \\
\hline CMBAZ_063 & $13-08-2016$ & -21.517941 & 35.498976 & 15.3 & 64 & Lighthouse \\
\hline CMBAZ_064 & $13-08-2016$ & -21.51316 & 35.499162 & 24.6 & 69 & Lighthouse \\
\hline CMBAZ_065 & $13-08-2016$ & -21.50957 & 35.494884 & 35.7 & 69 & Lighthouse \\
\hline CMBAZ_066 & $13-08-2016$ & -21.506307 & 35.490353 & 33.1 & 72 & Lighthouse \\
\hline CMBAZ_067 & $13-08-2016$ & -21.544535 & 35.497224 & 9.8 & 84 & Lighthouse \\
\hline CMBAZ_068 & $13-08-2016$ & -21.54934 & 35.499673 & 14.1 & 86 & Lighthouse \\
\hline CMBAZ_069 & $13-08-2016$ & -21.555157 & 35.499679 & 11.8 & 87 & Lighthouse \\
\hline CMLHR_085 & $15-08-2016$ & -22.262801 & 35.534222 & 8.9 & 72 & San Sebastian \\
\hline CMLHR_086 & $15-08-2016$ & -22.264943 & 35.539756 & 13.2 & 68 & San Sebastian \\
\hline CMLHR_087 & $15-08-2016$ & -22.270402 & 35.538763 & 10.8 & 66 & San Sebastian \\
\hline CMLHR_088 & $15-08-2016$ & -22.275284 & 35.538027 & 8.4 & 64 & San Sebastian \\
\hline CMLHR_089 & $15-08-2016$ & -22.280338 & 35.537885 & 8.5 & 64 & San Sebastian \\
\hline CMLHR_090 & $15-08-2016$ & -22.285354 & 35.538455 & 8.5 & 63 & San Sebastian \\
\hline
\end{tabular}




\begin{tabular}{|c|c|c|c|c|c|c|}
\hline CMLHR_091 & $15-08-2016$ & -22.290424 & 35.539797 & 10.3 & 61 & San Sebastian \\
\hline CMLHR_092 & $15-08-2016$ & -22.295514 & 35.540386 & 11.3 & 64 & San Sebastian \\
\hline CMLHR_093 & $15-08-2016$ & -22.300414 & 35.541788 & 10.4 & 64 & San Sebastian \\
\hline CMLHR_094 & $15-08-2016$ & -22.301438 & 35.54745 & 9.9 & 63 & San Sebastian \\
\hline CMLHR_095 & $15-08-2016$ & -22.303363 & 35.552102 & 11.8 & 64 & San Sebastian \\
\hline CMLHR_096 & $15-08-2016$ & -22.307897 & 35.55012 & 6.7 & 67 & San Sebastian \\
\hline CMLHR_097 & $15-08-2016$ & -22.326697 & 35.546211 & 7.2 & 62 & San Sebastian \\
\hline CMLHR_098 & $15-08-2016$ & -22.321433 & 35.54566 & 6.7 & 62 & San Sebastian \\
\hline CMLHR_099 & $15-08-2016$ & -22.317545 & 35.548227 & 9.4 & 64 & San Sebastian \\
\hline CMLHR_100 & $15-08-2016$ & -22.312746 & 35.546194 & 8.8 & 67 & San Sebastian \\
\hline CMLHR_101 & $15-08-2016$ & -22.309045 & 35.545577 & 9.8 & 66 & San Sebastian \\
\hline CMLHR_102 & $15-08-2016$ & -22.303983 & 35.547463 & 9.5 & 66 & San Sebastian \\
\hline CMLHR_103 & $15-08-2016$ & -22.244527 & 35.539859 & 17.1 & 66 & San Sebastian \\
\hline CMLHR_104 & $15-08-2016$ & -22.252933 & 35.532477 & 10.5 & 67 & San Sebastian \\
\hline CMLHR_105 & $15-08-2016$ & -22.260094 & 35.535833 & 11.1 & 66 & San Sebastian \\
\hline CMLHR_106 & $15-08-2016$ & -22.266386 & 35.540508 & 15.2 & 63 & San Sebastian \\
\hline CMLHR_107 & $15-08-2016$ & -22.272334 & 35.538457 & 11.2 & 60 & San Sebastian \\
\hline CMLHR_108 & $15-08-2016$ & -22.278166 & 35.537386 & 8.6 & 60 & San Sebastian \\
\hline CMLHR_122 & 19-08-2016 & -22.253062 & 35.533501 & 8.8 & 65 & San Sebastian \\
\hline CMLHR_123 & $19-08-2016$ & -22.255887 & 35.537599 & 11.3 & 65 & San Sebastian \\
\hline CMLHR_124 & 19-08-2016 & -22.262139 & 35.53829 & 10.4 & 66 & San Sebastian \\
\hline CMLHR_125 & $19-08-2016$ & -22.267276 & 35.538181 & 9.7 & 66 & San Sebastian \\
\hline CMLHR_126 & $19-08-2016$ & -22.272065 & 35.53831 & 9.1 & 61 & San Sebastian \\
\hline CMLHR_127 & 19-08-2016 & -22.276431 & 35.53837 & 10.3 & 66 & San Sebastian \\
\hline CMLHR_128 & $19-08-2016$ & -22.282278 & 35.538283 & 7.4 & 60 & San Sebastian \\
\hline CMLHR_129 & 19-08-2016 & -22.289479 & 35.539114 & 8.6 & 61 & San Sebastian \\
\hline CMLHR_130 & $19-08-2016$ & -22.294898 & 35.540105 & 10.3 & 62 & San Sebastian \\
\hline CMLHR_131 & 19-08-2016 & -22.296379 & 35.547619 & 10.4 & 62 & San Sebastian \\
\hline CMLHR_132 & 19-08-2016 & -22.301537 & 35.547651 & 6.8 & 62 & San Sebastian \\
\hline CMLHR_133 & 19-08-2016 & 35.550743 & -22.306796 & 8.2 & 58 & San Sebastian \\
\hline CMLHR_134 & 19-08-2016 & 35.549456 & -22.311136 & 7.3 & 60 & San Sebastian \\
\hline CMLHR_135 & $19-08-2016$ & 35.548494 & -22.316135 & 9.4 & 60 & San Sebastian \\
\hline CMLHR_136 & 19-08-2016 & -22.321193 & 35.546931 & 10.7 & 61 & San Sebastian \\
\hline CMLHR_137 & 19-08-2016 & -22.325398 & 35.545687 & 4.8 & 60 & San Sebastian \\
\hline CMLHR_138 & 19-08-2016 & -22.330622 & 35.546321 & 7.2 & 61 & San Sebastian \\
\hline CMLHR_139 & $19-08-2016$ & -22.337616 & 35.546014 & 7.6 & 62 & San Sebastian \\
\hline CMLHR_142 & 20-08-2016 & -22.29778 & 35.55336 & 15 & 82 & San Sebastian \\
\hline CMLHR_143 & 20-08-2016 & -22.301957 & 35.554236 & 17.8 & 74 & San Sebastian \\
\hline CMLHR_144 & 20-08-2016 & -22.294463 & 35.566941 & 25 & 72 & San Sebastian \\
\hline CMLHR_145 & 20-08-2016 & -22.300117 & 35.568934 & 28.5 & 71 & San Sebastian \\
\hline CMLHR_146 & 20-08-2016 & 35.564765 & -22.305804 & 22.4 & 69 & San Sebastian \\
\hline CMLHR_147 & 20-08-2016 & -22.31246 & 35.561234 & 21.9 & 63 & San Sebastian \\
\hline
\end{tabular}


Table S2: Functional categories, targeting status ( $T=$ targeted) and relative abundance of fish species observed using baited remote underwater video stations at Lighthouse and San Sebastian reefs, southern Mozambique. Functional categories: $\mathrm{H}=$ herbivore; $\mathrm{O}=$ omnivore; $\mathrm{BSI}=$ browser of sessile invertebrates; $\mathrm{DC}=$ diurnal carnivore; $\mathrm{NC}=$ nocturnal carnivore; $\mathrm{PI}$ $=$ piscivore; $\mathrm{DP}=$ diurnal planktivore; and NP = nocturnal planktivore

[Please check spelling of Bennet/Bennett. Not consistent. With regard to when to use parenthesis for a particular naming authority and date, please see 'Species nomenclature' in the journal's latest Instructions to Authors. This has not been applied correctly here. However, in a non-taxonomic paper, the authorities are not necessary, and hence a much simpler option would simply be to delete all of them. It would have the advantage of shortening the table considerably.]

\begin{tabular}{|c|c|c|c|c|c|c|}
\hline \multirow[b]{2}{*}{ Taxon } & \multicolumn{6}{|c|}{ Relative abundance } \\
\hline & $\begin{array}{l}\text { Functional } \\
\text { category }\end{array}$ & $\begin{array}{l}\text { Targeting } \\
\text { status }\end{array}$ & $\begin{array}{l}\text { Lighthouse } \\
\text { Reef mean }\end{array}$ & $\begin{array}{l}\text { Lighthouse } \\
\text { Reef SE }\end{array}$ & $\begin{array}{c}\text { San } \\
\text { Sebastian } \\
\text { Reef mean }\end{array}$ & $\begin{array}{l}\text { San Sebastian } \\
\text { Reef SE }\end{array}$ \\
\hline \multicolumn{7}{|l|}{ ACANTHURIDAE } \\
\hline Acanthurus dussumieri & $\mathrm{H}$ & & 1.67 & 0.82 & 3.66 & 0.54 \\
\hline Acanthurus leucocheilus & $\mathrm{H}$ & & 1.83 & 1.24 & 1.59 & 0.51 \\
\hline Acanthurus leucosternon & $\mathrm{H}$ & & 0.07 & 0.07 & 0.57 & 0.21 \\
\hline Acanthurus mata & DP & & 1.6 & 0.82 & 2.05 & 0.72 \\
\hline Acanthurus tennenti & $\mathrm{H}$ & $\mathrm{T}$ & 2.43 & 0.73 & 1.68 & 0.42 \\
\hline Acanthurus thompsoni & $\mathrm{H}$ & & 0.43 & 0.21 & 0.07 & 0.04 \\
\hline Acanthurus triostegus & $\mathrm{H}$ & & 1.77 & 1.2 & 0.07 & 0.07 \\
\hline Acanthurus xanthopterus & DP & & 0.17 & 0.14 & 1.02 & 0.43 \\
\hline Ctenochaetus striatus & $\mathrm{H}$ & & 5.13 & 1.1 & 4.41 & 0.86 \\
\hline Ctenochaetus truncatus & $\mathrm{H}$ & & 0 & 0 & 0.02 & 0.02 \\
\hline Naso brachycentron & $\mathrm{H}$ & & 0.43 & 0.25 & 0.34 & 0.11 \\
\hline Naso brevirostris & $\mathrm{H}$ & & 0.5 & 0.23 & 1.39 & 0.61 \\
\hline Naso elegans & $\mathrm{H}$ & & 0.17 & 0.08 & 0.77 & 0.22 \\
\hline Naso hexacanthus & $\mathrm{H}$ & & 0.13 & 0.09 & 0 & 0 \\
\hline Naso tonganus & $\mathrm{H}$ & & 0.07 & 0.05 & 0.02 & 0.02 \\
\hline Naso unicornis & $\mathrm{H}$ & & 1.97 & 0.7 & 1.64 & 0.6 \\
\hline Zebrasoma scopas & $\mathrm{H}$ & & 0.1 & 0.06 & 0 & 0 \\
\hline \multicolumn{7}{|l|}{ ANTENNARIIDAE } \\
\hline Antennarius nummifer & PI & & 0.03 & 0.03 & 0 & 0 \\
\hline \multicolumn{7}{|l|}{ APOGONIDAE } \\
\hline Apogon aureus & DC & & 0.23 & 0.23 & 2.91 & 2.91 \\
\hline \multicolumn{7}{|l|}{ AULOSTOMIDAE } \\
\hline Aulostomus chinensis & $\mathrm{PI}$ & & 0.03 & 0.03 & 0.02 & 0.02 \\
\hline \multicolumn{7}{|l|}{ BALISTIDAE } \\
\hline Abalistes stellatus & DC & & 0.03 & 0.03 & 0 & 0 \\
\hline Balistapus undulatus & $\mathrm{DC}$ & & 0.1 & 0.06 & 0.41 & 0.11 \\
\hline Balistoides conspicillum & $\mathrm{DC}$ & & 0.07 & 0.07 & 0.34 & 0.09 \\
\hline Balistoides viridescens & $\mathrm{DC}$ & & 0.3 & 0.15 & 0.3 & 0.08 \\
\hline Melichthys indicus & O & & 0.2 & 0.09 & 0.07 & 0.05 \\
\hline Odonus niger & DP & & 1.77 & 1.43 & 3.11 & 1.86 \\
\hline $\begin{array}{l}\text { Pseudobalistes } \\
\text { flavimarginatus }\end{array}$ & DC & & 0.07 & 0.05 & 0.18 & 0.07 \\
\hline
\end{tabular}


BLENNIIDAE

Ecsenius midas

CAESIONIDAE

Caesio caerulaurea

Caesio xanthonota

\section{CARANGIDAE}

Carangoides ferdau

DC

Caranx melampygus

DC

Caranx sexfasciatus

Decapterus macarellus

Gnathanodon speciosus

Scomberoides lysan

Seriolina nigrofasciata

CARCHARHINIDAE

Carcharhinus amblyrhynchos

PI

Carcharhinus melanopterus

Triaenodon obesus

CHAETODONTIDAE

Chaetodon auriga

Chaetodon bennetti

Chaetodon blackburnii

Chaetodon falcula

Chaetodon guttatissimus

BSI

BSI

Chaetodon interruptus

Chaetodon kleinii

BSI

BSI

Chaetodon lineolatus

Chaetodon lunula

madagaskariensis

Chaetodon melannotus

Chaetodon meyeri

BSI

0.73

0.22

0.14

BSI

BSI

Chaetodon trifascialis

Chaetodon trifasciatus

Chaetodon vagabundus

Chaetodon xanthocephalus

BSI

0.82

Forcipiger flavissimus 
Paracirrhites arcatus

Paracirrhites forsteri

DASYATIDAE

Himantura fai

Himantura jenkinsii

Himantura uarnak

DIODONTIDAE

Diodon hystrix

ECHENEIDAE

Echeneis naucrates

NC

0.27

0.08

0.45

0.11

EPHIPPIDAE

Platax orbicularis

O

Tripterodon orbis

FISTULARIIDAE

Fistularia commersonii

HAEMULIDAE

Plectorhinchus

flavomaculatus

Plectorhinchus gaterinus

Plectorhinchus plagiodesmus

Plectorhinchus playfairi

Plectorhinchus schotaf

HOLOCENTRIDAE

Myripristis murdjan

Sargocentron

caudimaculatum

Sargocentron diadema

KYPHOSIDAE

Kyphosus cinerascens

LABRIDAE

Anampses caeruleopunctatus

Anampses meleagrides

Bodianus anthioides

Bodianus axillaris

Bodianus bilunulatus

Bodianus diana

Bodianus perditio

Cheilinus trilobatus

Cheilio inermis

Cirrhilabrus exquisitus

Coris aygula

Coris caudimacula

Coris cuvieri

Coris formosa

Gomphosus caeruleus

Halichoeres cosmetus

Halichoeres hortulanus

Halichoeres iridis

Halichoeres nebulosus

Halichoeres scapularis

Hemigymnus fasciatus

Hologymnosus annulatus

Hologymnosus doliatus

Iniistius pavo

$\begin{array}{cc}0 & 0 \\ 0.03 & 0.03\end{array}$

0.05

0.03

NC

0

0.02

0.02

NC

0

0.11

0.05

DC

0.1

0.06

0

0

0.09

PI

0.17

0.07

0.07

0.04

NC

0.47

0.18

0.57

0.11

NC

0.07

0.07

0

0.14

0.07

0.27

0.17

0.52

0.05

DC

NC

$\mathrm{T}$

0.11

NP

0.17

0.17

0.05

0.05

NC

NC

0.2

0.1

0.05

0.03

0.03

0.03

0.41

0.21

0.83

0.83

0.66

0.27

DC

0.03

0.03

0.09

0.09

0.04

DC

0.1

0.06

0.02

0.04

0.02

0.17

0
0.11

0.16

$0.08 \quad 0.52$

0.06

0.11

0.53

0.17

0.66

0.13

0.05

0.03

0.07

0.07

0.05

0.06

0.27

0.13

0.16

0.14

0.23

0.06

0.08

0.17

0.19

0.82

0.02

0.07

0.05

0.02

0.13

0.13

0.59

0.43

0.1

0.17

1.11

0.05

0.17

0.05

$0.13 \quad 0.39$

0.12

0.16

0.1

0.06

0.04

0.02 
Iniistius pentadactylus $\quad$ DC

Labroides bicolor

Labroides dimidiatus

Macropharyngodon bipartitus

Novaculichthys taeniourus

Pseudodax moluccanus

Stethojulis albovittata

Thalassoma amblycephalum

Thalassoma hebraicum

Thalassoma lunare

LETHRINIDAE

Lethrinus crocineus

Lethrinus harak

Lethrinus microdon

Monotaxis grandoculis

LUTJANIDAE

Aphareus furca

Aprion virescens

Lutjanus bengalensis

Lutjanus bohar

Lutjanus ehrenbergii

Lutjanus fulviflamma

Lutjanus gibbus

Lutjanus kasmira

Lutjanus lutjanus

Lutjanus rivulatus

Macolor niger

MALACANTHIDAE

Malacanthus brevirostris

Malacanthus latovittatus

MICRODESMIDAE

Gunnellichthys monostigma

MOBULIDAE

Manta birostris

MONACANTHIDAE

Aluterus scriptus

Cantherhines dumerilii

Cantherhines pardalis

MONODACTYLIDAE

Monodactylus argenteus

MULLIDAE

Mulloidichthys flavolineatus

Mulloidichthys vanicolensis

Parupeneus barberinus

Parupeneus cyclostomus

Parupeneus indicus

Parupeneus macronema

Parupeneus pleurostigma

Parupeneus rubescens

Parupeneus trifasciatus

MURAENIDAE

Gymnothorax favagineus

Gymnothorax flavimarginatus

O

$\mathrm{PI}$

$\mathrm{PI}$

0
DC

$D C$

$D C$

DC

DC

$\mathrm{DC}$

DC

DC

NC

$\mathrm{NC}$

NC

NC

0.23

0.3

0.87

0

0

0.03

0.4

0.83

1.8

1

1

1.1

0.1

0.3

0.12

0.02

0.02

0.15

0.25

0.3

1.34

0.02

0.02

0.45

0.27

5.57

3.98

4.57

0.09

0.29

0.02

0.02

0.11

0.08

1.68

0.62

0.93

0.31

0.59

0.16

0.42

0.41

0.11

0.27

0.12

0.64

0.35

NC

NC

$\mathrm{NC}$

NC

NC

$\mathrm{NC}$

NC

NC

NC

DC

NC

0.1

0.06

0.11

0.06

0.2

1.75

0.61

0.33

0

0.37

0.07

0.16

0.93

0.5

0.19

0

2.66

4.16

1.72

1.08

3.63

12.54

29.07

0.14

0.11

0.1

0.15

0.02

0.27

0.02

0.16

0.09

0.27

0.6

0.6

0

0

DP

0

0.05

0.03

BSI

BSI

0.07
0

0.33

0.07

0.05

0.03

$0 \quad 0.02$

0.02

0.1

0.32

0.07

DP

0

0

3.18

3.18

NC

0.13

0.08

0.73

3.43

0.05

1.23

0.73

0.14

0.41

0.03

DC

0.43

0.18

0.61

0.23

0.08

0.45

0.12

0.14

1.87

0.44

2.52

0.37

0.14

0.43

0.31

0.23

0.12

0.43

0.13

0.34

0.1

$\mathrm{NC}$

NC
0.2

0.32

0.06

0.09 
NEMIPTERIDAE

Scolopsis bimaculata

Scolopsis ghanam

DC

DC

0.07

OPLEGNATHIDAE

Oplegnathus robinsoni

OSTRACIIDAE

Ostracion cubicus

PINGUIPEDIDAE

Parapercis clathrata

Parapercis hexophtalma

POMACANTHIDAE

Apolemichthys trimaculatus

Centropyge multispinis

Pomacanthus imperator

Pomacanthus rhomboides

$\mathrm{O}$

BSI

DC

Pomacanthus semicirculatus

POMACENTRIDAE

Abudefduf sparoides

Abudefduf vaigiensis

Amphiprion allardi

Chromis fieldi

Chromis weberi

\section{Dascyllus trimaculatus}

Neopomacentrus cyanomos

Pomacentrus caeruleus

O

PRIACANTHIDAE

Priacanthus hamrur

PTEROIDAE

Pterois miles

RHINOBATIDAE

Rhynchobatus djiddensis

SCARIDAE

Calotomus carolinus

Chlororus sordidus

Scarus caudofasciatus

Scarus frenatus

Scarus ghobban

Scarus persicus

Scarus rubroviolaceus

Scarus tricolor 
SERRANIDAE

Aethaloperca rogaa

Cephalopholis argus

Cephalopholis miniata

Cephalopholis nigripinnis

Epinephelus

coeruleopunctatus

Epinephelus fasciatus

Epinephelus lanceolatus

Epinephelus macrospilos

Epinephelus malabaricus

Epinephelus multinotatus

Epinephelus tukula

$\begin{array}{ccc}\mathrm{NC} & \mathrm{T} & 0.03 \\ \mathrm{PI} & \mathrm{T} & 0.4 \\ \mathrm{NC} & \mathrm{T} & 0.17\end{array}$

0.03

0.25

0.07

NC T

0.17
0.13

0.15

0.07

0.04

$\mathrm{NC}$

0.1

0.36

0.12

PI

0

0.02

0.02

NC

0

0.05

0.05

$\mathrm{NC}$

0.07

0.05

0.43

0.15

DC

0.03

0.16

0.06

0.03

0.02

0.02

0.33

0.11

0.3

0.09

PI

0

0.02

0.02

Pseudanthias squamipinnis

NC

0

0.14

0.05

Variola louti

PI

1.32

4.23

1.93

0.14

0.05

SIGANIDAE

Siganus luridus

Siganus sutor

\section{SPARIDAE}

Rhabdosargus sarba

DC

0

0.45

6.66

2.27

SPHYRAENIDAE

Sphyraena barracuda

Sphyraena putnamae

DC

NC

0.03

0

0.03

7.41

0

7.41

TETRAODONTIDAE

Arothron hispidus

$\mathrm{NC}$

Arothron mappa

$\mathrm{NC}$

Arothron nigropunctatus

$\mathrm{NC}$

Canthigaster bennetti

O

Canthigaster valentini

$\mathrm{O}$

$\begin{array}{cccc}0 & 0 & 0.07 & 0.04 \\ 0.03 & 0.03 & 0.02 & 0.02 \\ 0 & 0 & 0.07 & 0.04 \\ 0.5 & 0.16 & 0.14 & 0.05 \\ 0.1 & 0.07 & 0.25 & 0.08\end{array}$

ZANCLIDAE

Zanclus cornutus

BSI

5.33

4.1

1.61

0.27 
Table S3: Functional structure of fish communities on southwest Indian Ocean reefs, expressed as percentages of total numbers of species (species richness). In the previous studies data were collected on the outer reef slope using underwater visual census (UVC), whereas baited remote underwater video stations (BRUVS) were used in the present study

\begin{tabular}{|c|c|c|c|c|c|c|}
\hline Site & Study & Technique & Carnivores & Omnivores & Herbivores & No. species \\
\hline Tofo/Barra & Fordyce (2016) & UVC & $80 \%$ & $8 \%$ & $9 \%$ & 324 \\
\hline Ponta Malongane & Floros et al. (2012) & UVC & $78 \%$ & $11 \%$ & $11 \%$ & 284 \\
\hline Andavadoaka & Gillibrand et al. (2007) & UVC & $76 \%$ & $11 \%$ & $13 \%$ & 334 \\
\hline Bazaruto Archipelago & Maggs et al. (2010) & UVC & $76 \%$ & $12 \%$ & $12 \%$ & 249 \\
\hline Tuléar & Harmelin-Vivien (1979) & UVC & $74 \%$ & $13.5 \%$ & $12.5 \%$ & 323 \\
\hline Juan de Nova & Chabanet-Durville (2005) & UVC & $73 \%$ & $11 \%$ & $16 \%$ & 299 \\
\hline Glorieuses & Durvile et al. (2003) & UVC & $73 \%$ & $12 \%$ & $15 \%$ & 332 \\
\hline Mayotte & Chabanet (2002) & UVC & $69 \%$ & $12.5 \%$ & $18.5 \%$ & 225 \\
\hline Geyser et Zélée & Chabanet et al. (2002) & UVC & $69 \%$ & $16 \%$ & $15 \%$ & 294 \\
\hline Réunion & Chabanet (1994) & UVC & $51 \%$ & $24 \%$ & $25 \%$ & 257 \\
\hline Lighthouse Reef & Present study & BRUVS & $80 \%$ & $7 \%$ & $13 \%$ & 189 \\
\hline San Sebastian Reef & Present study & BRUVS & $81 \%$ & $8 \%$ & $11 \%$ & 195 \\
\hline
\end{tabular}

Figure S1: Schematic of lightweight aluminium baited remote underwater video station (BRUVS) (AIMS Engineering Workshops ${ }^{\odot}$ ) used during deployments in southern Mozambique, showing frame, underwater camera housings, and bait arm with bait bag attached

Figure S2[renamed, was Figure S3]: Variance partitioning of explanatory variables in top-ranked model (negative binomial generalised linear model) of target fish abundance (MaxN) in southern Mozambique

Figure S3[renamed, was Figure S2]: Cluster analysis, using SIMPROF, of the compositions by genera of reef-fish communities at Lighthouse and San Sebastian reefs in 2016. The different shades indicate groups that SIMPROF determined were significantly different. The percentage of baited remote underwater video stations (BRUVS) occurring in each significant cluster are shown at the two sites (San Sebastian Reef and Lighthouse Reef) (middle graph) and in the three major habitats (lower graph) 
Figure S4: Map of regional study sites listed in Supplementary Table S3 